\title{
RESEARCH ON THE DETERMINATION OF RECREATIONAL EXPERIENCE PREFERENCES, EXPECTATIONS, AND SATISFACTION LEVELS OF LOCAL PEOPLE
}

\author{
İhsan Kurar \\ Independent Researcher \\ Email: ihsankurar@hotmail.com
}

Received: 11 February 2021. Revision received: 25 April 2021. Accepted: 5 May 2021

\begin{abstract}
This study aims to determine Recreational Experience Preferences (REP) of the local people in Alanya, their leisure constraints, their expectations for recreational activities from the local authority, and the level of their satisfaction with recreational areas. Within the scope of the study, the data was collected via a questionnaire from 384 participants who visit recreational areas in Alanya through a convenience sampling method. The most preferred recreational activities of the local people are going on a picnic, visiting friends, and internet surfing. However, the three most important variables limiting the participation of the local people in recreational activities have been identified as lack of leisure time, not enough money, and pollution of toilets, fountains, and wash-hand basins in the region. The three most important expectations of the local people from the local authority in terms of recreational activities are the construction of new recreational areas, ensuring that everyone benefits from the facilities, and cleaning toilets, fountains, and wash-hand basins in the region. In addition, it has been determined that three of the most important motivations that lead the local people to recreational activities are having a good time, mental relaxation, and family togetherness experiences. According to the findings of this study, the level of satisfaction of the local people with the recreational areas is quite low. Besides, The ANOVA results indicated that people demographic characteristics had a significant influence on recreation experience preference.
\end{abstract}

KEYWORDS: Leisure, recreation, recreation motivation, recreation experience preferences, REP

JEL CLASSIFICATION: Z32, L83, L84

Reference: Kurar, İ. (2021). Research on the determination of recreational experience preferences, expectations, and satisfaction levels of local people. International Journal of Entrepreneurial Knowledge, 9(1), 41-66. doi: 10.37335/ijek.v9i1.122

\section{INTRODUCTION}

Time is a process where events come down and pursue each other toward the future, and which continues without interruption and beyond one's control (Smith et al., 2010: 59). Therefore, it is almost impossible to bring time under control and make saving in this respect. However, quantity and quality of time may be increased by using time efficiently and in a planned manner. Time (chronos) that means "chronological time" in Greek is linear and sequential. Accordingly, no second is more valuable than any other second and essentially, it is hour that determines the living rhythm of people (Tengilimoğlu et al., 2011: 44-45). However, different cultures have "kairos", i.e. suitable or quality time approach. Kairos time considers the benefit obtained, while chronos time considers the time spent (Cummings, 2008: 150-151).

Almost everything that spends time lead people to the stress that there is not enough time. Stress causes people to become misfit and causes disruption of working order of the entire team by leading to conflicts in working environment and causing minor problems to become strange (Raffoni, 2006: 15-16). Therefore, today, many people face serious health and social problems such as depression, obesity, diabetes, and suicide due to stress (Ashby and Rice, 2002: 197).

Recreational activities have positive effects on health and mental health of people. With this aspect, professionals of recreation and community health advocate making physical activities fun, safe, and 


\section{INTERNATIONAL JOURNAL OF ENTREPRENEURIAL KNOWLEDGE}

Issue 1, volume 9, ISSN 2336-2960 (Online)

www.ijek.org

accessible to stop the alarming trend in health of people because the positive emotions felt during participation in recreational activities directly affect the quality of life positively (California Outdoor Recreation Planning Program [CORP], 2005: 13). Nonetheless Increases in life satisfaction exert negative effects on working hours in countries with low working hours, while it has a positive effect on working hours in countries with high working hours (Nadirov et al., 2017: 277).

In this study, it is aimed to determine recreational experience preferences of the local people in Alanya, their leisure constraints, their expectations for recreational activities from the local authority, and the level of their satisfaction with recreational areas. In parallel with the objective of the study, active or passive recreational preferences of the local people have been determined through the recreational experience preferences scale developed within the concept of motivation theories. From this aspect, the study is expected to contribute to research to be conducted on recreational areas in terms of examining the behaviors of people, and to the body of literature related to recreation.

Findings of the research data are shared with Alanya local authority organizations and advices are given to make up shortages and open new recreational areas in order for the local people to participate in recreational activities. Thus, contribution is made to the national and regional planning of social recreational organizations.

The most significant aspect of this study that makes it different from the others is that it reveals the motivations that lead people to recreational activities. In this study, firstly, a theoretical framework on recreational experience preferences of the local people and their level of location-centered satisfaction with recreational areas was established. Then, the results of the data collected were evaluated and suggestions were made.

\section{LITERATURE REVIEW}

It is a known fact that there is an increasing dissatisfaction, stress, difficulties, immobility, deprivation of creativity, and becoming isolated in the structure of many societies around the world. However, it is possible to relieve these through leisure time activities (Sivan and Ruskin, 2000: 1-2). Today, many activities contain many aspects of work and leisure time. Therefore, while any activity is the time to work for some people, it is considered a recreational activity by others (Torkildsen, 2005: 46). Thus, first, it is necessary to determine types of time by their intended use. By its intended use, time can be examined under three main groups, namely time to work, time to satisfy physiological needs, and leisure time (Hazar, 2014: 8-9).

According to Roberts (1979: 2), time to work is based on a formal organization that is paid, specialized, and has generally accepted rules, such as obligations, being disciplined, and organizational rules. During the time when physiological needs are satisfied, basic needs necessary to survive such as eating, drinking, and sleeping are satisfied (Wang, 2008: 33-38).

Free time is the time remaining after work, sleep, and personal care (Goodale and Witt, 1980: 21). Spare time is the time spent without making any activity (Mieczkowski, 1990: 9-10). Residual time is the time that remains after working time and that can be allocated to many activities such as beliefs, family, and entertainment. Participation in recreational activities is generally performed in residual time (Shores, 2005: 2). Leisure time is the situation where one's time is freed from the requirements of his/her work or duty (Butler, 2013: 10).

According to Butler (1968: 3), recreation is considered a different activity experience, an anti-work activity, or an activity performed to renew. On the other hand, Driver (1983: 1-10) defines recreation as 


\section{INTERNATIONAL JOURNAL OF ENTREPRENEURIAL KNOWLEDGE}

Issue 1, volume 9, ISSN 2336-2960 (Online)

www.ijek.org

any event one voluntarily participates in order to gain some physical, social, and emotional behaviors personally or in a group in his/her free time. Recreation is an activity selected by people to participate in their leisure time according to Broadhurst (2001: 2); is an activity selected freely and performed voluntarily by people in their leisure time according to $\mathrm{Lu}$ and $\mathrm{Hu}$ (2005: 325); and is spending leisure time with active or passive participation according to Stebbins (2005: 349). Active participation means activities requiring active participation of people, i.e. entertainment and culture, walking and hiking, other sports, outdoor activities, other computing activities, other hobbies and games, reading books, other reading, travel related to leisure activities. On the other hand, passive participation is the situation where people utilize their leisure time as audience of a certain activity, i.e. visits and feasting, other social life, relaxing, computer and video games, TV and video, radio and music, unspecified leisure activities (Jankiewicz, 2015: 205).

People participate in a recreational activity when there is a problem, i.e. when the current situation does not coincide with the desired situation (Knopf et al., 1973: 191-204). For this reason, people desire to select the most suitable activity for them in order to maximize the benefit they will obtain during their limited leisure time (Ateca-Amestoy et al., 2008: 65-66). On the other hand, according to the scientists who consider leisure time as an activity (De Grazia, 1962: 7, Pieper, 1963: 43, Dumazedier, 1974: 136137, Tinsley and Tinsley, 1986: 45, Haywood et. al., 1989: 2, Torkildsen, 2005: 26), the best determinant of leisure time experience is the level of pleasure and satisfaction with the activity.

According to Driver and Tocher (1970: 1-10), recreational activities are behavioral occupations used to achieve certain psychological and physical objectives. With this aspect, recreation benefit means how participation in recreational activities contributes to one's becoming more functional after participating in an activity (Driver, 1976: 163). In other words, spending leisure time means that person is him/herself, shows his/her talents, and person's capacity and potential (Payne et al., 2002: 11). For example; while some people consider watching TV as an uplifting leisure time activity, others may consider it as a monotone and meaningless leisure time activity (Wang, 2008: 28-34).

While some recreational experience preferences depend to a large extent on features of physical resources, the rate of dependency on resource may vary by activities. Each of these activities may give satisfaction or dissatisfaction at the same time (Driver, 1976: 164). For this reason, there are subjective and objective criteria between people and the place to spend leisure time (Giuliani and Feldman, 1993: 269). Subjective criterion tries to measure leisure time based on experiences of people. For example; in their study, Lloyd and Auld (2002: 44) tried to reveal whether the person-centered factors such as sense of achievement, social interaction, and one's attitude for and level of satisfaction with the recreational activities are dominant on quality of life. On the other hand, objective criterion aims to measure leisure time excluding experiences of people. Traditionally, objective criterion is identified with the locationcentered point of view (public parks, sport complexes, and service usage frequency), while subjective criterion is identified with the person-centered point of view (Lloyd and Auld, 2002: 43).

According to Sivan and Ruskin (2000: 1-2), leisure time and recreational activities are perceived as an important resource in increasing the quality of life of people because people's attitude to leisure time has highly important impacts on both the status of participation in leisure time activities and the level of satisfaction with such participation (Lloyd and Auld, 2002: 46). Recreational activities are not only the activities such as watching TV, listening to music, working out, nature walk, camping, going on a picnic and fishing, etc. (Manfredo et al., 1996: 189). Therefore, knowing what motivates people for participation in activities and how such motivations affect a satisfactory experience will enable a better understanding of such experiences (Sivan and Ruskin, 2000: 1-2). For determining what motivates people for participation in activities in their leisure time, the recreational experience preferences scales developed within the concept of motivation theories are commonly used (Manfredo et al., 1996: 189). 


\section{INTERNATIONAL JOURNAL OF ENTREPRENEURIAL KNOWLEDGE}

Issue 1, volume 9, ISSN 2336-2960 (Online)

www.ijek.org

Leisure time motivation research model was developed for the first time by Driver and Tocher (1970: 110) at the end of 1960's. This approach was used in the later years in research on recreational experiences by Knopf et al. (1973: 191-204), Driver and Brown (1975: 10-12), Driver and Knopf (1977: 169-193), and Brown and Haas (1980: 22-241). These scales both help to determine the reason for leisure time behaviors of people and contribute to the understanding of results of participation in leisure time activities (Driver, 1983: 1-10).

For example; a person who gets stressed due to the overload of life problems may want to go fishing in order to temporarily move away from the responsibilities of daily life. Thus, he/she will fulfill a motivating stimulation (Wellman, 1979: 61-73). In addition, while people demonstrate specialization in any activity, their recreational experience preferences may also change (Smith et al., 2010: 59). A kind of fishery activity performed with the desire for developing skills may also make contribution to the increase of self-confidence of people (Driver, 1976: 176). However, those desiring fishing may also prefer such experiences that are not specific to activity such as being with friends or out (Ditton et al., 1992: 33). Since the participation of people with recreational experience preferences in activities vary, the environment where they have recreational experiences and the recreational experience preferences they have also change.

\section{METHODOLOGY}

\subsection{Objectives of The Study}

In this study, it is aimed to determine recreational experience preferences of the local people in Alanya, their leisure constraints, their expectations from the local authority, and the level of their satisfaction with recreational areas because healthy people who are mentally and physically strong are expected to be more productive and willing in their job (Özdağ et al., 2009: 310). Information on leisure time motivation helps the development of programs that minimize problems between operators and users, and that will provide more benefit to humans (Manfredo et al., 1996: 188). It is essential to make up shortages in the region, if any, through determinations to be made accordingly, to plan investments and activities aimed at demands, to rationally use opportunities that are limited, and to make new facilities and activities more objectiveoriented (Özdağ et al., 2009: 310). Answers will be sought for the following questions and hypothesis in line with the objective of this research.

\section{Research Questions}

Research Questions 1 - What is the demographical profile of participants in recreational activities? Research Questions 2 - What is the level of the attitude of participants to recreational activities? Research Questions 3 - What is the level of the recreational activity preferences of the local people and of their participation (leisure constraints) in recreational activities?

Research Questions 4 - What are the expectations of the local people from the local authority for recreational areas?

Research Questions 5 - What is the level of satisfaction of the local people with the recreational areas in Alanya?

Research Questions 6 - What are the recreational experience preferences of the local people?

\section{Hypotheses}

Hypothesis $1_{1}$ : The recreation experience preferences in Alanya is vary due to differences in gender of the people. 


\section{INTERNATIONAL JOURNAL OF ENTREPRENEURIAL KNOWLEDGE}

Issue 1, volume 9, ISSN 2336-2960 (Online)

www.ijek.org

Hypothesis $2{ }_{1}$ : The recreation experience preferences in Alanya is vary due to differences in gender of the people.

Hypothesis $3_{1}$ : The recreation experience preferences in Alanya is vary due to differences in professions of the people.

Hypothesis $4_{1}$ : The recreation experience preferences in Alanya is vary due to differences in residence of the people.

Hypothesis $5_{1}$ : The recreation experience preferences in Alanya is vary due to differences in education of the people.

Hypothesis $6_{1}$ : The recreation experience preferences in Alanya is vary due to differences in age of the people.

Hypothesis 71: The recreation experience preferences in Alanya is vary due to differences in income of the people.

Hypothesis $8_{1}$ : There is a relationship between the recreation experience preference and location-centered satisfaction.

Hypothesis $9_{1}$ : Recreation experience preferences positively affect location-centered satisfaction.

\subsection{Description of the Study of Area and Sample}

Alanya, with a bed capacity of 308.848 and an annual average number of 6.693 .646 tourists, is an extremely significant tourism destination among the Mediterranean countries. The local people residing in Alanya constitutes the population. The population of Alanya is 327.503 persons including 42,882 resident foreigners. Alanya is located in the Mediterranean Region, $135 \mathrm{~km}$ east from Antalya. The research population consists of the 161.915 local people, who are over the age of 18 and over, living in Alanya. Second home owner living in the destination are not included in the sample. Because in many studies, although second home owner reside in the destination for a long time, they are still tourists. Although local people and tourists visit same recreation areas, locals have recreational experience and tourists, on the other hand, have tourist experience.

Sampling was taken into account as it wasn't possible to reach all individuals. Accordingly, considering that the sample should represent the population well, it has been tried to reach individuals with different socio-cultural and socio-economic characteristics as much as possible. As the sampling method, convenience sampling method was chosen among the non-probabilistic sampling methods.

As is seen in Figure 1, the locations in the district where the research was conducted are marked with numbers on the map. This study was carried out with the participation of the local people of Alanya on 15 November-15 December 2019. There is no data on whether the local people living in Alanya use recreative areas. For this reason, the questionnaire of the research was applied face to face by using the convenience sampling method among nonrandom sample methods. Accordingly, the number of questionnaires required to be achieved was determined with the formula $n=t^{2} \cdot p \cdot q / d^{2}$ (Baş, 2006: 42).

When the sample size is calculated with a sampling error of $5 \%$ for the values $p=0.5$ and $q=0.5$ and $\mathrm{t}=1.96$ with the reliability interval of $95 \%(\alpha=0.05), 384$ is found. Within the scope of the study carried out, 402 questionnaires were applied and the sufficient size of sample was achieved. However, since the data loss in eighteen questionnaires exceeded approximately $20 \%$, they were not included in the analysis. Thus, the analyses were performed based on the remaining 384 questionnaires. Although a sufficient number of samples was achieved for the research, the most important constraints of the research comprise time and cost. Some participants received a phone call during the interview. And Some of the other participants stated their boredom. Therefore, we could not continue the survey.

Figure 1 Study Area (Alanya District Map) 


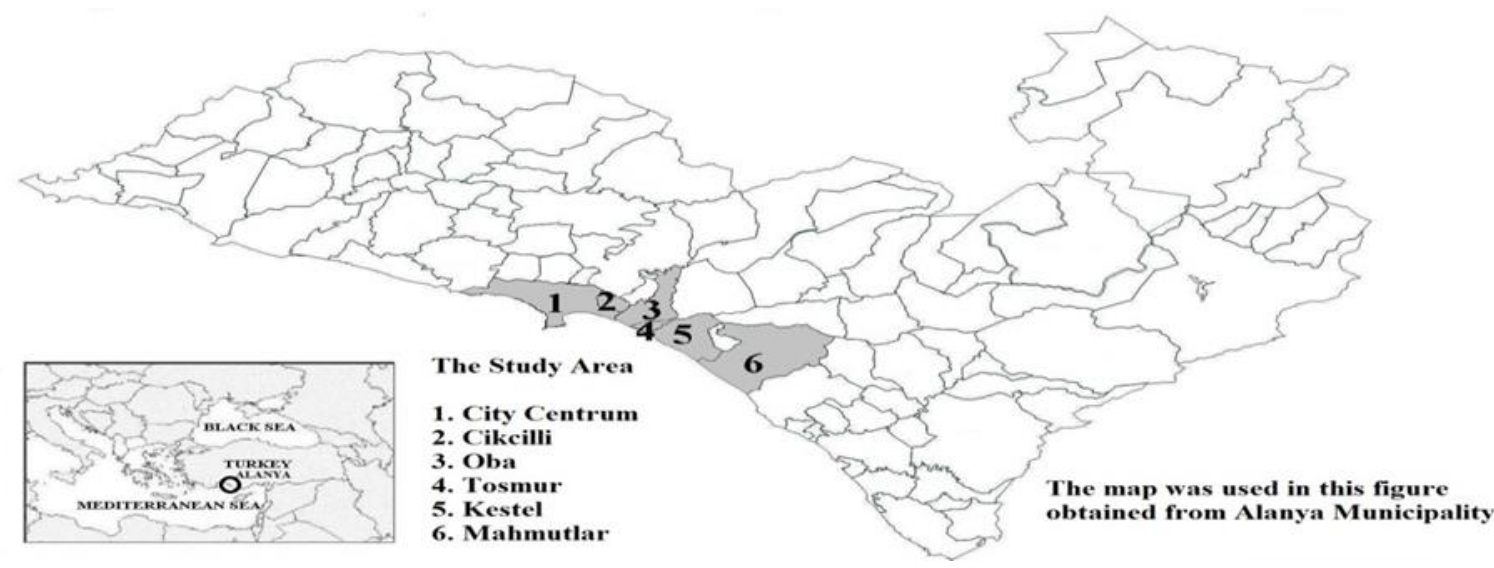

\subsection{Date Collection Method of the Research}

Primary and secondary data was utilized in the research. A questionnaire was prepared as the primary data collection tool in line with the existing literature (Hacioğlu et al., 2005, Kuo, 2011, Driver, 1983, Manfredo et al., 1996, Lee et al., 2002, Lloyd and Auld, 2002, Sivan and Ruskin, 2000, Kurar 2019).

The questionnaire form so prepared reached 402 persons through face to face interviews. The questionnaire includes 17 questions in total. The first seven questions in the questionnaire comprise the participants' demographic characteristics, activities, leisure constraints, and expectations from the local authority. Activities and expectations were selected from the list created by Hacioğlu et al. (2005), while leisure constraints were selected from the list created by Kuo (2011).

The recreational experience preferences scales were developed within the concept of motivation theories. With this aspect, 8th question of the questionnaire comprises twelve motivation elements that were selected, similar with the research made by Manfredo et al. (1996: 188-213) and Lee et al. (2002: 18-37), from the list of Driver (1976: 163-189) that includes 19 motivation and 320 items. In order to simplify the questionnaire process, it was preferred to use in subscales single elements that represent different experiences of the people while making recreational experience preferences, rather than using multiple elements. The 9-11th questions in the questionnaire are for the scale of satisfaction (Table 5) with the location-centered recreational services as used in his research by Kurar (2019: 710).

During the research, it was determined that the value of the scale $(\alpha)$ of the recreational experience preferences of the local people that comprises 12 motivations was 0,757 and that the value of the location-centered satisfaction scale $(\alpha)$ was 0,781 . For the questions of the questionnaire, the 5-point Likert scale ( $1=$ Not important at all, $5=$ Very important) was used except for demographic questions. The significance degree of $\mathrm{p}<0.05$ was used for interpretation of the results. Findings are included with the demographic profile of the participants, multiple answers, t test, Anova, correlation and regression analysis subheadings. Some abbreviations were used in the research. (i.e. $\overline{\mathrm{X}}=$ Mean; S.D. $=$ Std. Deviation; M.D. = Mean Differences; $\mathrm{f}=$ Frequency; AVE=Average Variance Extracted; CR=Composite Reliability).

\section{EMPIRICAL RESULTS}

\subsection{Findings on research questions (Q)}

For the purposes of the study, the following research questions were examined: 
INTERNATIONAL JOURNAL OF ENTREPRENEURIAL KNOWLEDGE

Issue 1, volume 9, ISSN 2336-2960 (Online)

www.ijek.org

Research Questions 1: What is the demographical profile of participants in recreational activities?

With the first question of the research, the findings related to the demographic variables of the participants are included.

\section{Table 1 Demographic characteristics of the respondents}

\begin{tabular}{|c|c|c|c|c|c|c|c|c|}
\hline Gender & $\mathrm{f}$ & $\%$ & Household income & $\mathrm{f}$ & $\%$ & Occupation & $\mathrm{f}$ & $\%$ \\
\hline Female & 153 & 39,8 & Less than 1000€ & 123 & 32,0 & Officials & 126 & 32,8 \\
\hline Male & 231 & 60,2 & $1000-2000 €$ & 118 & 37,7 & Self-employed people & 70 & 18,2 \\
\hline Total & 384 & 100 & $2001-3000 €$ & 107 & 27,9 & Employees & 139 & 36,2 \\
\hline Marital Status & $\mathrm{f}$ & $\%$ & More than 3001 E & 36 & 9,6 & Retirement & 49 & 4,7 \\
\hline Single & 154 & 40,1 & Total & 384 & 100 & Total & 384 & 100 \\
\hline Married & 230 & 59,9 & Age group & $\mathrm{f}$ & $\%$ & Education levels & $\mathrm{f}$ & $\%$ \\
\hline Total & 384 & 100 & $18-25$ & 87 & 22,7 & Primary school & 76 & 19,8 \\
\hline Residence & $f$ & $\%$ & $26-33$ & 134 & 34,9 & High school & 98 & 25,5 \\
\hline Less than 3 years & 92 & 24,0 & $34-41$ & 87 & 22,7 & Associate Degree & 43 & 11,2 \\
\hline $3-5$ years & 42 & 10,9 & $42-49$ & 50 & 13,0 & Facultydegrees & 97 & 25,3 \\
\hline More than 5 years & 250 & 65,1 & More than 50 years & 26 & 6,8 & Masters degrees & 70 & 18,2 \\
\hline Total & 384 & 100 & Total & 384 & 100 & Total & 384 & 100 \\
\hline
\end{tabular}

The demographic characteristics of the participants in the research are provided in table 1 . Accordingly, the majority of the participants are male $(60.2 \%)$, married $(59.9 \%), 26-33$ years old $(34.9 \%)$, worker (36.2\%), high-school graduate (25.5\%), have an income of TRY 1000-2000 (37.7\%), and have resided in the region for more than 5 years $(65.1 \%)$.

Research Questions 2: What is the level of the attitude of participants to recreational activities?

The second question of the research is intended for determining the behaviours of the questionnaire participants towards recreational activities. The interpretations on the findings of the research are provided based on the number of participants $(n=384)$.

\section{Table 2 Multiple answers}

\begin{tabular}{|c|c|c|c|c|c|c|c|}
\hline \multirow{2}{*}{ Recreation Area } & \multicolumn{2}{|c|}{ Responded } & \multirow{2}{*}{$\begin{array}{l}\text { Percent } \% \\
(n=384)\end{array}$} & \multirow{2}{*}{ Hours } & \multicolumn{2}{|c|}{ Responded } & \multirow{2}{*}{$\begin{array}{c}\text { Percent } \% \\
(n=384)\end{array}$} \\
\hline & f & $\%$ & & & $\mathrm{f}$ & $\%$ & \\
\hline Outdoor & 239 & 52,5 & 62,2 & $1-2$ hour & 201 & 52,2 & 52,9 \\
\hline Indoor & 144 & 31,6 & 37,5 & 3-4 hour & 107 & 27,8 & 28,2 \\
\hline Sports & 57 & 12,5 & 14,8 & More than 4 hours & 42 & 10,9 & 11,1 \\
\hline Others & 15 & 3,3 & 3,9 & Less than 1 hour & 35 & 9,1 & 9,2 \\
\hline Total & 455 & 100 & 118,5 & Total & 385 & 100 & 101,3 \\
\hline \multirow{2}{*}{ Times } & \multicolumn{2}{|c|}{ Responded } & Percent \% & \multirow{2}{*}{ Months } & \multicolumn{2}{|c|}{ Responded } & Percent \% \\
\hline & $\mathrm{f}$ & $\%$ & $(n=384)$ & & f & $\%$ & $(n=384)$ \\
\hline Evening & 297 & 66,3 & 79,4 & July & 200 & 18,9 & 52,1 \\
\hline Midday & 76 & 17,0 & 20,3 & August & 184 & 17,4 & 47,9 \\
\hline Morning & 56 & 12,5 & 15,0 & June & 150 & 14,2 & 39,1 \\
\hline Others & 19 & 4,2 & 5,1 & January & 78 & 7,4 & 20,3 \\
\hline Total & 448 & 100 & 119,8 & February & 74 & 7,0 & 19,3 \\
\hline \multirow{2}{*}{ Participants } & \multicolumn{2}{|c|}{ Responded } & \multirow{2}{*}{$\begin{array}{c}\text { Percent } \% \\
(n=384)\end{array}$} & March & 62 & 5,8 & 16,1 \\
\hline & $\mathrm{f}$ & $\%$ & & September & 60 & 5,7 & 15,6 \\
\hline Friends & 185 & 43,1 & 48,6 & May & 59 & 5,6 & 15,4 \\
\hline My wife and children & 103 & 24,0 & 27,0 & December & 57 & 5,4 & 14,8 \\
\hline Only my wife & 69 & 16,1 & 18,1 & April & 51 & 4,8 & 13,3 \\
\hline Alone & 47 & 11,0 & 12,3 & November & 43 & 4,1 & 11,2 \\
\hline Children & 18 & 4,2 & 4,7 & October & 42 & 4,0 & 10,9 \\
\hline Others & 7 & 1,6 & 1,8 & Total & 1060 & 100 & 276,0 \\
\hline Total & 429 & 100 & 112,6 & & & & \\
\hline
\end{tabular}




\section{INTERNATIONAL JOURNAL OF ENTREPRENEURIAL KNOWLEDGE}

Issue 1, volume 9, ISSN 2336-2960 (Online)

www.ijek.org

As is seen in table 2, the majority of the local people perform recreational activities outdoor $(62.2 \%)$, for 1-2 hours $(52.9 \%)$, in the evening $(79.4 \%)$, with their friends (48.6\%), and in July $(52.1 \%)$, August $(47.9 \%)$, and June $(39.1 \%)$.

Research Questions 3: What is the level of the recreational activity preferences of the local people and of their participation (leisure constraints) in recreational activities?

The third question for which an answer was sought concerns both what the level of preferences of the local people for recreational activities is, and what the leisure constraints are. In this section of the research that includes the questions with multiple answer options, it has been determined that the participants have marked 1485 options regarding the recreational activities they perform more, and 1032 options regarding leisure constraints. However, the interpretations on the findings are provided based on the number of participants $(n=384)$.

\section{Table 3 Recreational activities and leisure constraints}

\begin{tabular}{|c|c|c|c|c|c|c|c|}
\hline \multirow{2}{*}{ Activity } & \multicolumn{2}{|c|}{ Responded } & \multirow{2}{*}{$\begin{array}{c}\text { Percent \% } \\
(n=384)\end{array}$} & \multirow{2}{*}{ Leisure constraints } & \multicolumn{2}{|c|}{ Responded } & \multirow{2}{*}{$\begin{array}{c}\text { Percent \% } \\
(n=384)\end{array}$} \\
\hline & $\mathrm{f}$ & $\%$ & & & f & $\%$ & \\
\hline Picnic & 235 & 15,8 & 61,2 & Lack of leisure time & 221 & 21,4 & 57,6 \\
\hline Visiting friends & 198 & 13,3 & 51,6 & Not enough money & 143 & 13,9 & 37,2 \\
\hline Internet surfing & 162 & 10,9 & 42,2 & Pollution of toilets, fountains & 89 & 8,6 & 23,2 \\
\hline Swimming & 149 & 10,0 & 38,8 & Inadequate transportation & 87 & 8,4 & 22,7 \\
\hline Music & 142 & 9,6 & 37,0 & Pollution in activity areas & 82 & 7,9 & 21,4 \\
\hline Newspaper and magazine & 141 & 9,5 & 36,7 & Inadequate information & 76 & 7,4 & 19,8 \\
\hline Cinema / Theater & 123 & 8,3 & 32,0 & Crowded activity areas & 75 & 7,3 & 19,5 \\
\hline Book & 110 & 7,4 & 28,6 & No companion & 72 & 7,0 & 18,8 \\
\hline Sports competition & 90 & 6,1 & 23,4 & Poorly maintained areas & 49 & 4,7 & 12,8 \\
\hline Gardening & 82 & 5,5 & 21,4 & Outdoor pests in activity areas & 45 & 4,4 & 11,7 \\
\hline Cafe & 33 & 2,2 & 8,6 & Inadequate facilities & 42 & 4,1 & 10,9 \\
\hline Other & 20 & 1,3 & 5,2 & Physically-limiting disability & 25 & 2,4 & 6,5 \\
\hline \multirow[t]{3}{*}{ Total } & 1485 & 100 & 386,7 & Safety concerns & 18 & 1,7 & 4,7 \\
\hline & & & & Other & 8 & 0,8 & 2,1 \\
\hline & & & & Total & 1032 & 100 & 268,8 \\
\hline
\end{tabular}

When Table 3 is examined, it has been determined that the majority of the participants prefer going on a picnic $(61.2 \%)$, visiting friends (51.6\%), internet surfing $(42.2 \%)$, and other $(5,2 \%)$. The other option includes shopping, participating in daily tours and watching television. However, it has been determined that the majority of the local people do not participate in recreational activities due to lack of leisure time $(57.6 \%)$, not enough money $(37.2 \%)$, and pollution of toilets, fountains and wash-hand basins in the region $(23.2 \%)$. The other option is personal health reason and/or household member with disability.

Research Questions 4: What are the expectations of the local people from the local authority for recreational areas?

The fourth question of the research concerns the determination of the expectations of the local people from the local authority for recreational areas. In this section of the research that includes the questions with multiple answer options, it has been determined that the participants have marked 1985 options regarding their expectations from the local authority. However, the interpretations on the findings are provided based on the number of participants $(n=384)$.

\section{Table 4 Expectations from local authority}

\begin{tabular}{|l|l|l|}
\hline Expectations & Responded & Percent \% (n=384) \\
\hline
\end{tabular}


INTERNATIONAL JOURNAL OF ENTREPRENEURIAL KNOWLEDGE

Issue 1, volume 9, ISSN 2336-2960 (Online)

www.ijek.org

\begin{tabular}{|c|c|c|c|}
\hline & f & $\%$ & \\
\hline New recreational areas/environment & 257 & 12,9 & 66,9 \\
\hline Everyone benefits from recreational facilities & 211 & 10,6 & 54,9 \\
\hline Cleaning of toilets, fountains and sink & 192 & 9,7 & 50,0 \\
\hline Organizing events with artistic value & 181 & 9,1 & 47,1 \\
\hline Municipal recreation units should be functionalized & 170 & 8,6 & 44,3 \\
\hline WC, Number of sinks should be increased & 159 & 8,0 & 41,4 \\
\hline Furniture and sports equipment should be maintained regularly & 156 & 7,9 & 40,6 \\
\hline Informing about the activities should be given & 144 & 7,3 & 37,5 \\
\hline Summer period inspections should be increased & 142 & 7,2 & 37,0 \\
\hline Conducting existing inspections regularly & 142 & 7,2 & 37,0 \\
\hline Trash in areas & 128 & 6,4 & 33,3 \\
\hline Outdoor pests in activity areas & 103 & 5,2 & 26,8 \\
\hline Total & 1985 & 100 & 516,9 \\
\hline
\end{tabular}

According to Table 4, it has been determined that the majority of the participants expect from the local authority construction of new areas $(66.9 \%)$, ensuring that everyone benefits from recreational facilities $(54.9 \%)$, cleaning of areas (50\%), and organizing events with artistic value (47.1\%).

Research Questions 5: What are the recreational experience preferences of the local people?

The fifth question of the research for which an answer was sought includes the ranking related to recreational experience preferences of the local people.

Table 5 Significance of factors effective in participants' REP

\begin{tabular}{|c|c|c|c|c|c|c|c|c|c|c|c|c|}
\hline \multirow{3}{*}{$\begin{array}{l}\text { Recreation Experience } \\
\text { Preferences Scale (REP) }\end{array}$} & \multirow{2}{*}{\multicolumn{2}{|c|}{$\begin{array}{c}\text { Not } \\
\text { important } \\
\text { at all }\end{array}$}} & \multirow{2}{*}{\multicolumn{2}{|c|}{$\begin{array}{c}\begin{array}{c}\text { Not very } \\
\text { important }\end{array} \\
2\end{array}$}} & \multirow{2}{*}{\multicolumn{2}{|c|}{$\begin{array}{c}\begin{array}{c}\text { Don't } \\
\text { Know }\end{array} \\
3\end{array}$}} & \multirow{2}{*}{\multicolumn{2}{|c|}{$\begin{array}{c}\text { Important } \\
4\end{array}$}} & \multirow{2}{*}{\multicolumn{2}{|c|}{$\begin{array}{c}\begin{array}{c}\text { Very } \\
\text { important }\end{array} \\
5\end{array}$}} & \multirow[t]{3}{*}{$\overline{\mathrm{x}}$} & \multirow[t]{3}{*}{ s.s } \\
\hline & & & & & & & & & & & & \\
\hline & $f$ & $\%$ & $\mathrm{f}$ & $\%$ & f & $\%$ & f & $\%$ & $f$ & $\%$ & & \\
\hline F1-Having good time & 5 & 1,3 & 5 & 1,3 & 24 & 6,3 & 144 & 37,5 & 206 & 53,6 & 4,40 & ,77 \\
\hline F3- Mental relaxation & 6 & 1,6 & 14 & 3,6 & 41 & 10,7 & 135 & 35,2 & 188 & 49,0 & 4,26 & ,90 \\
\hline F2- Family togetherness & 20 & 5,2 & 14 & 3,6 & 38 & 9,9 & 129 & 33,6 & 183 & 47,7 & 4,14 & 1,08 \\
\hline F7- Physical Fitness & 10 & 2,6 & 23 & 6,0 & 63 & 16,4 & 138 & 35,9 & 150 & 39,1 & 4,02 & 1,01 \\
\hline F5- Being with Friends & 11 & 2,9 & 24 & 6,3 & 42 & 10,9 & 180 & 46,9 & 127 & 33,1 & 4,01 & ,97 \\
\hline F4- Having a different experience & 16 & 4,2 & 21 & 5,5 & 55 & 14,3 & 146 & 38,0 & 146 & 38,0 & 4,00 & 1,05 \\
\hline F6- To be where it is cooler & 14 & 3,6 & 24 & 6,3 & 76 & 19, & 128 & 33,3 & 14 & 37,0 & 3,93 & 1,07 \\
\hline F8-Knowledge and skills experience & 10 & 2,6 & 26 & 6,8 & 69 & 18,0 & 156 & 40,6 & 123 & 32,0 & 3,92 & 1,00 \\
\hline F9- Escape Daily Routine & 32 & 8,3 & 22 & 5,7 & 72 & 18,8 & 128 & 33,3 & 130 & 33,9 & 3,78 & 1,20 \\
\hline F10-Knowing new persons & 15 & 3,9 & 32 & 8,3 & 102 & 26,6 & 150 & 39,1 & 85 & 22,1 & 3,67 & 1,03 \\
\hline F11-Achievement & 37 & 9,6 & 39 & 10,2 & 86 & 22,4 & 115 & 29,9 & 107 & 27,9 & 3,56 & 1,26 \\
\hline F12- Escaping family & 79 & 20,6 & 72 & 18,8 & 89 & 23,2 & 90 & 23,4 & 54 & 14,1 & 2,91 & 1,34 \\
\hline
\end{tabular}

Table 5 provides the motivations that lead the participants to recreational activities. The participants of the research make recreational experience preferences for having good time $(\overline{\mathrm{x}}=4.40)$, mental relaxation $(\overline{\mathrm{x}}=4.26)$, and family togetherness $(\overline{\mathrm{x}}=4.14)$. However, the least preferred recreational experience preferences are knowing new persons $(\overline{\mathrm{x}}=3.67)$, achievement $(\overline{\mathrm{x}}=3.56)$, and moving away from the family environment temporarily $(\overline{\mathrm{x}}=2.91)$.

Research Questions 6: What is the level of Location-centered satisfaction of the local people with the recreational areas in Alanya? 
INTERNATIONAL JOURNAL OF ENTREPRENEURIAL KNOWLEDGE

Issue 1, volume 9, ISSN 2336-2960 (Online)

www.ijek.org

In table 6 , the propositions about the location-centered satisfaction scale created to determine the satisfaction level of the participants with the recreational areas were subjected to confirmatory factor analysis. It was found that $\mathrm{x}^{2} / \mathrm{df}=2.17$ and some indexes RMSEA, GFI, AGFI, CFI, RMR and SRMR showed excellent fitting indexes. The convergent validity of the measurement model can be assessed by the Average Variance Extracted (AVE) and Composite Reliability (CR). Acceptable values for CR is over .70 and for AVE over .70 which is accepted as excellent value but AVE must be over .50 (Fornell ve Larcker (1981:45). In this research, the CR of the satisfaction dimension is greater than 0.70 . In addition, the AVE value for the satisfaction dimension was calculated 0.68 .

Table 6 Location-centered satisfaction scale t-Value, factor loadings and indices

\begin{tabular}{|c|c|c|c|c|c|c|c|c|}
\hline Component & \multicolumn{2}{|c|}{ Code } & $\operatorname{Mean}(\overline{\mathrm{x}})$ & $\begin{array}{c}\text { Factor } \\
\text { Loadings }\end{array}$ & \multicolumn{2}{|c|}{ t-Value } & \multicolumn{2}{|c|}{$\%$ of Variance } \\
\hline \multirow{3}{*}{$\begin{array}{l}\text { Location- } \\
\text { Centered } \\
\text { Satisfaction } \\
\quad(\text { LCS })\end{array}$} & \multicolumn{2}{|c|}{$\begin{array}{l}\text { Q1-I am satisfied with privately } \\
\text { owned recreation areas. }\end{array}$} & 3,04 & 0.76 & \multicolumn{2}{|c|}{ - } & \multicolumn{2}{|c|}{0.47} \\
\hline & \multicolumn{2}{|c|}{$\begin{array}{l}\text { Q2-I am satisfied with public } \\
\text { sector recreation areas. }\end{array}$} & 3,08 & 0.68 & \multicolumn{2}{|c|}{14.29} & \multicolumn{2}{|c|}{0.45} \\
\hline & \multicolumn{2}{|c|}{$\begin{array}{l}\text { Q3-Recreation areas are } \\
\text { sufficient. }\end{array}$} & 3,36 & 0.78 & \multicolumn{2}{|c|}{16.06} & \multicolumn{2}{|c|}{0.34} \\
\hline Measures & Ki-Kare $\left(\chi^{2}\right)$ & $\chi^{2 / d f}$ & RMSEA & GFI & AGFI & CFI & RMR & SRMR \\
\hline Threshold & $2,17(\mathrm{P}=0.14)$ & 2,17 & 0.048 & 0.98 & 0.97 & 0.96 & 0.0094 & 0.0068 \\
\hline Status & Not Significant & Traditional & Great & Great & Great & Great & Great & Great \\
\hline
\end{tabular}

$\overline{\mathbf{A V E}}=0,68$ and $\mathbf{C R}=0,91$

It has been determined that the factor loadings of the propositions are below 1.00. In terms of these fit values, it is understood that there is a harmony between the model and the observed data, and the proposed model is at an acceptable level. The combined reliability of the satisfaction dimension is greater than 0.70. In addition, the AVE value for the satisfaction dimension was calculated 0.50 and above. This dimension appears to have a medium average.

\subsection{Findings on hypothesis}

In this section: The nine hypothesis of the research reveals whether the recreational experience preferences of the local people vary by demographic variables, with t-test and anova analysis, correlation and multiple regression analysis. In addition, since the variances are homogenous $(p>0.05)$ according to the homogeneity of variances test (Levene), LSD test was applied in order to find between which groups there is mean difference (M.D.) (Kalayc1, 2010: 321-332). If the Sig. value is greater than or equal to (with $95 \%$ confidence interval), we reject the alternative hypothesis $\mathrm{H}_{1}$.

$\mathbf{H 1}_{1}$ : The recreation experience preferences in Alanya is vary due to differences in gender of the people.

Table 7 Independed sample t-Test results based on gender sample

\begin{tabular}{|c|c|c|c|c|c|c|c|c|c|c|}
\hline \multicolumn{2}{|c|}{$\begin{array}{c}\text { Independent } \\
\text { variable }\end{array}$} & \multirow{2}{*}{$\begin{array}{c}\text { Factor } \\
\%\end{array}$} & \multicolumn{2}{|c|}{$\begin{array}{l}\text { Being with } \\
\text { friends }\end{array}$} & \multicolumn{2}{|c|}{$\begin{array}{l}\text { Meeting new } \\
\text { people }\end{array}$} & \multicolumn{2}{|c|}{$\begin{array}{c}\text { Knowledge and skills } \\
\text { experience }\end{array}$} & \multicolumn{2}{|c|}{ Physical fitness } \\
\hline Gender & f & & $\overline{\mathrm{x}}$ & S.D. & $\overline{\mathrm{x}}$ & S.D. & $\overline{\mathrm{x}}$ & S.D. & $\overline{\mathrm{x}}$ & S.D. \\
\hline Female & 153 & 39,8 & 4,13 & ,87 & 3,80 & 96 & 4,09 & 90 & 4,23 & 90 \\
\hline Male & 231 & 60,2 & 3,93 & 1,02 & 3,58 & 1,07 & 3,81 & 1,04 & 3,89 & 1,05 \\
\hline \multicolumn{3}{|c|}{ t-value } & \multicolumn{2}{|c|}{1,976} & \multicolumn{2}{|c|}{2,047} & \multicolumn{2}{|c|}{2,746} & \multicolumn{2}{|c|}{3,288} \\
\hline \multicolumn{3}{|c|}{$\mathrm{p}$ value } & \multicolumn{2}{|c|}{0,049} & \multicolumn{2}{|c|}{,041 } & \multicolumn{2}{|c|}{,006 } & \multicolumn{2}{|c|}{0,001} \\
\hline \multicolumn{3}{|c|}{ H1 } & \multicolumn{2}{|c|}{ Accepted } & \multicolumn{2}{|c|}{ Accepted } & \multicolumn{2}{|c|}{ Accepted } & \multicolumn{2}{|c|}{ Accepted } \\
\hline \multicolumn{2}{|c|}{$\begin{array}{l}\text { Independent } \\
\text { variable }\end{array}$} & Factor & \multicolumn{2}{|c|}{ Escaping family } & \multicolumn{2}{|c|}{ Achievement } & \multicolumn{2}{|c|}{$\begin{array}{l}\text { Having a different } \\
\text { experience }\end{array}$} & \multicolumn{2}{|c|}{$\begin{array}{l}\text { Having good } \\
\text { time }\end{array}$} \\
\hline
\end{tabular}


INTERNATIONAL JOURNAL OF ENTREPRENEURIAL KNOWLEDGE

Issue 1, volume 9, ISSN 2336-2960 (Online)

www.ijek.org

\begin{tabular}{|c|c|c|c|c|c|c|c|c|c|c|}
\hline Gender & $\mathrm{f}$ & $\%$ & $\overline{\mathrm{x}}$ & S.D. & $\overline{\mathrm{x}}$ & S.D. & $\overline{\mathrm{x}}$ & S.D. & $\overline{\mathrm{x}}$ & S.D. \\
\hline Female & 153 & 39,8 & 3,20 & 1,32 & 3,85 & 1,14 & 4,15 & 1,00 & 4,53 & 86 \\
\hline Male & 231 & 60,2 & 2,72 & 1,32 & 3,36 & 1,29 & 3,90 & 1,08 & 4,32 & 1,00 \\
\hline \multicolumn{3}{|c|}{ t-value } & \multicolumn{2}{|c|}{3,553} & \multicolumn{2}{|c|}{3,780} & \multicolumn{2}{|c|}{2,238} & \multicolumn{2}{|c|}{2,681} \\
\hline \multicolumn{3}{|c|}{$\mathrm{p}$ value } & \multicolumn{2}{|c|}{,000 } & \multicolumn{2}{|c|}{0,000} & \multicolumn{2}{|c|}{,026 } & \multicolumn{2}{|c|}{,009 } \\
\hline \multicolumn{3}{|c|}{ H1 } & \multicolumn{2}{|c|}{ Accepted } & \multicolumn{2}{|c|}{ Accepted } & \multicolumn{2}{|c|}{ Accepted } & \multicolumn{2}{|c|}{ Accepted } \\
\hline \multicolumn{2}{|c|}{$\begin{array}{c}\text { Independent } \\
\text { variable }\end{array}$} & Factor & \multicolumn{2}{|c|}{$\begin{array}{c}\text { Family } \\
\text { togetherness }\end{array}$} & \multicolumn{2}{|c|}{$\begin{array}{c}\text { Mental } \\
\text { relaxation }\end{array}$} & \multicolumn{2}{|c|}{$\begin{array}{c}\text { Escape daily } \\
\text { routine }\end{array}$} & \multicolumn{2}{|c|}{$\begin{array}{c}\text { To be where it } \\
\text { is cooler }\end{array}$} \\
\hline Gender & f & $\%$ & $\overline{\mathrm{x}}$ & S.D. & $\overline{\mathrm{x}}$ & S.D. & $\overline{\mathrm{x}}$ & S.D. & $\overline{\mathrm{x}}$ & S.D. \\
\hline Female & 153 & 39,8 & 4,26 & ,98 & 4,34 & ,78 & 3,85 & 1,18 & 4,01 & 1,07 \\
\hline Male & 231 & 60,2 & 4,06 & 1,13 & 4,20 & ,97 & 3,74 & 1,22 & 3,88 & 1,06 \\
\hline \multicolumn{3}{|c|}{ t-value } & \multicolumn{2}{|c|}{1,766} & \multicolumn{2}{|c|}{1,475} & \multicolumn{2}{|c|}{,919 } & \multicolumn{2}{|c|}{1,127} \\
\hline \multicolumn{3}{|c|}{ p value } & \multicolumn{2}{|c|}{,078 } & \multicolumn{2}{|c|}{,141 } & \multicolumn{2}{|c|}{, 358} & \multicolumn{2}{|c|}{,261 } \\
\hline \multicolumn{3}{|c|}{ H1 } & \multicolumn{2}{|c|}{ Rejected } & \multicolumn{2}{|c|}{ Rejected } & \multicolumn{2}{|c|}{ Rejected } & \multicolumn{2}{|c|}{ Rejected } \\
\hline
\end{tabular}

Independent $t$ test was performed on the recreation experience preferences scale ratings of the people from different gender group from Alanya. The results of the SPSS output matrix were shown in table 7. The $\mathrm{p}$ values of some the components of the recreation experience preferences were greater than 0.05 family togetherness, mental relaxation, escape daily routine and to be where it is cooler and $\mathrm{H}_{1}$ was rejected in these four components of recreation experience preferences. $\mathrm{H} 1_{1}$ cannot be rejected being with friends, meeting new people, knowledge and skills experience, physical fitness, escaping family, achievement, having a different experience and having good time dimensions of the recreation experience preferences.

H21: The recreation experience preferences in Alanya is vary due to differences in gender of the people.

Table 8 Independed sample t-Test results based on marital status sample

\begin{tabular}{|c|c|c|c|c|c|c|c|c|c|c|}
\hline \multicolumn{2}{|c|}{ Independent variable } & \multirow{2}{*}{$\begin{array}{c}\text { Factor } \\
\%\end{array}$} & \multicolumn{2}{|c|}{$\begin{array}{l}\text { Being with } \\
\text { friends }\end{array}$} & \multicolumn{2}{|c|}{ Meeting new people } & \multicolumn{2}{|c|}{ Achievement } & \multicolumn{2}{|c|}{$\begin{array}{c}\text { Having a different } \\
\text { experience }\end{array}$} \\
\hline Marital Status & $\mathrm{f}$ & & $\overline{\mathrm{x}}$ & S.D. & $\overline{\mathrm{x}}$ & S.D. & $\overline{\mathrm{x}}$ & S.D. & $\overline{\mathrm{x}}$ & S.D. \\
\hline Single & 154 & 40,1 & 4,16 & ,92 & 3,81 & ,96 & 3,77 & 1,14 & 4,16 & ,99 \\
\hline Married & 230 & 59,9 & 3,90 & ,99 & 3,57 & 1,06 & 3,42 & 1,31 & 3,89 & 1,08 \\
\hline \multicolumn{3}{|c|}{ t-value } & \multicolumn{2}{|c|}{2,626} & \multicolumn{2}{|c|}{2,284} & \multicolumn{2}{|c|}{2,696} & \multicolumn{2}{|c|}{2,536} \\
\hline \multicolumn{3}{|c|}{ p value } & \multicolumn{2}{|c|}{,009 } & \multicolumn{2}{|c|}{0,023} & \multicolumn{2}{|c|}{,007 } & \multicolumn{2}{|c|}{,012 } \\
\hline \multicolumn{3}{|c|}{$\mathbf{H} 2$} & \multicolumn{2}{|c|}{ Accepted } & \multicolumn{2}{|c|}{ Accepted } & \multicolumn{2}{|c|}{ Accepted } & \multicolumn{2}{|c|}{ Accepted } \\
\hline \multicolumn{2}{|c|}{ Independent variable } & Factor & \multicolumn{2}{|c|}{$\begin{array}{c}\text { Family } \\
\text { togetherness }\end{array}$} & \multicolumn{2}{|c|}{$\begin{array}{l}\text { Knowledge and } \\
\text { skills experience }\end{array}$} & \multicolumn{2}{|c|}{ Physical fitness } & \multicolumn{2}{|c|}{ Mental relaxation } \\
\hline Marital Status & f & $\%$ & $\overline{\mathrm{x}}$ & S.D. & $\overline{\mathrm{x}}$ & S.D. & $\overline{\mathrm{x}}$ & S.D. & $\overline{\mathrm{x}}$ & S.D. \\
\hline Single & 154 & 40,1 & 4,05 & 1,07 & 4,00 & ,97 & 4,06 & 1,06 & 4,31 & ,94 \\
\hline Married & 230 & 59,9 & 4,20 & 1,08 & 3,87 & 1,01 & 4,00 & ,98 & 4,22 &, 87 \\
\hline \multicolumn{3}{|c|}{ t-value } & \multicolumn{2}{|c|}{$-1,335$} & \multicolumn{2}{|c|}{1,168} & \multicolumn{2}{|c|}{,573 } & \multicolumn{2}{|c|}{,979 } \\
\hline \multicolumn{3}{|c|}{$\mathrm{p}$ value } & \multicolumn{2}{|c|}{,183 } & \multicolumn{2}{|c|}{,243 } & \multicolumn{2}{|c|}{, 567} & & \\
\hline & & & & & & & & & & \\
\hline Independent va & ble & Factor & $\begin{array}{r}\text { Esc } \\
\mathrm{r}\end{array}$ & $\begin{array}{l}\text { daily } \\
\text { ne }\end{array}$ & Esca & amily & $\begin{array}{r}\text { To be } \\
\mathrm{c}\end{array}$ & $r$ & Havir & d time \\
\hline Marital Status & $\mathrm{f}$ & $\%$ & $\overline{\mathrm{x}}$ & S.D. & $\overline{\mathrm{x}}$ & S.D. & $\overline{\mathrm{x}}$ & S.D. & $\overline{\mathrm{x}}$ & S.D. \\
\hline Single & 154 & 40,1 & 3,91 & 1,14 & 3,00 & 1,28 & 3,91 & 1,09 & 4,43 & ,76 \\
\hline Married & 230 & 59,9 & 3,70 & 1,24 & 2,85 & 138 & 3,95 & 1,06 & 4,39 & ,78 \\
\hline
\end{tabular}


INTERNATIONAL JOURNAL OF ENTREPRENEURIAL KNOWLEDGE

Issue 1, volume 9, ISSN 2336-2960 (Online)

www.ijek.org

\begin{tabular}{|c|c|c|c|c|}
\hline $\mathrm{t}$-value & $\mathbf{1 , 7 1 6}$ & $\mathbf{1 , 0 7 2}$ &,- 328 &, $\mathbf{5 4 1}$ \\
\hline $\mathrm{p}$ value &, $\mathbf{0 8 7}$ &, $\mathbf{5 8 4}$ &, 743 & $\mathbf{5 8 9}$ \\
\hline H2 & Rejected & Rejected & Rejected & Rejected \\
\hline
\end{tabular}

Again Independent $t$ test was performed on the recreation experience preferences scale ratings of the people from different marital status group from Alanya. The results of the SPSS output matrix were shown in table 8 . The $\mathrm{p}$ values of some the components of the recreation experience preferences were greater than 0.05 family togetherness, knowledge and skills experience, physical fitness, mental relaxation, escape daily routine, escaping family, to be where it is cooler and having good time and $\mathrm{H} 2{ }_{1}$ was rejected in these eight components of recreation experience preferences. $\mathrm{H} 2{ }_{1}$ cannot be rejected being with friends, meeting new people, achievement and having a different experience dimensions of the recreation experience preferences.

$\mathbf{H 3}_{1}$ : The recreation experience preferences in Alanya is vary due to differences in professions of the people.

Table 9 Anova analysis findings related to the professional group

\begin{tabular}{|c|c|c|c|c|c|c|c|c|c|c|}
\hline \multicolumn{2}{|c|}{ Independent variable } & \multirow{2}{*}{$\begin{array}{c}\text { Factor } \\
\% \\
\end{array}$} & \multicolumn{2}{|c|}{$\begin{array}{l}\text { Being with } \\
\text { friends }\end{array}$} & \multicolumn{2}{|c|}{$\begin{array}{c}\text { Knowledge and } \\
\text { skills experience }\end{array}$} & \multicolumn{2}{|c|}{ Escaping family } & \multicolumn{2}{|c|}{ Achievement } \\
\hline Professions & $\mathrm{f}$ & & $\overline{\mathrm{x}}$ & S.D. & $\overline{\mathrm{x}}$ & S.D. & $\overline{\mathrm{x}}$ & S.D. & $\overline{\mathrm{x}}$ & S.D. \\
\hline Officials & 126 & 32,8 & 4,15 & 88 & 3,73 & 1,04 & 2,61 & 1,25 & 3,30 & 1,24 \\
\hline Self-employed people & 70 & 18,2 & 3,68 & 1,12 & 3,92 & 1,10 & 2,74 & 1,31 & 3,47 & 1,31 \\
\hline Employees & 139 & 36,2 & 3,95 & ,99 & 4,15 & 84 & 3,17 & 1,33 & 3,89 & 1,12 \\
\hline Retirement & 49 & 4,7 & 4,24 &, 77 & 3,79 & 1,04 & 3,20 & 1,45 & 3,42 & 1,39 \\
\hline Total & 384 & 100 & 4,01 & 97 & 3,92 & 1,00 & 2,91 & 1,34 & 3,56 & 1,26 \\
\hline \multicolumn{3}{|c|}{ F } & \multicolumn{2}{|c|}{4,784} & \multicolumn{2}{|c|}{4,334} & \multicolumn{2}{|c|}{5,258} & \multicolumn{2}{|c|}{5,458} \\
\hline \multicolumn{3}{|c|}{ p value } & \multicolumn{2}{|c|}{,003 } & \multicolumn{2}{|c|}{, 005} & \multicolumn{2}{|c|}{,001 } & \multicolumn{2}{|c|}{,001 } \\
\hline \multicolumn{3}{|c|}{ Fisher's LSD post-hoc tests } & \multicolumn{2}{|c|}{$\begin{array}{l}\text { Self-employed } \\
\text { people }>\text { Officials }\end{array}$} & \multicolumn{2}{|c|}{$\begin{array}{c}\text { Employees> } \\
\text { Officials, } \\
\text { Retirement }\end{array}$} & \multicolumn{2}{|c|}{$\begin{array}{l}\text { Retirement> } \\
\text { Officials }\end{array}$} & \multicolumn{2}{|c|}{$\begin{array}{c}\text { Employees> } \\
\text { Officials, Self- } \\
\text { employed people }\end{array}$} \\
\hline \multicolumn{3}{|c|}{ H3 } & \multicolumn{2}{|c|}{ Accepted } & \multicolumn{2}{|c|}{ Accepted } & \multicolumn{2}{|c|}{ Accepted } & \multicolumn{2}{|c|}{ Accepted } \\
\hline \multicolumn{2}{|c|}{ Independent variable } & Factor & \multicolumn{2}{|c|}{$\begin{array}{c}\text { To be where it is } \\
\text { cooler }\end{array}$} & \multicolumn{2}{|c|}{$\begin{array}{c}\text { Family } \\
\text { togetherness }\end{array}$} & \multicolumn{2}{|c|}{$\begin{array}{c}\text { Meeting new } \\
\text { people }\end{array}$} & \multicolumn{2}{|c|}{ Physical fitness } \\
\hline Professions & f & $\%$ & $\overline{\mathrm{x}}$ & S.D. & $\overline{\mathrm{x}}$ & S.D. & $\overline{\mathrm{x}}$ & S.D. & $\overline{\mathrm{x}}$ & S.D. \\
\hline Officials & 126 & 32,8 & 3,63 & 1,07 & 4,00 & 1,13 & 3,62 & 1,01 & 4,04 & 92 \\
\hline Self-employed people & 70 & 18,2 & 3,97 & 1,16 & 4,15 & 128 & 3,65 & 1,07 & 3,88 & 1,22 \\
\hline Employees & 139 & 36,2 & 4,16 & 92 & 4,23 & ,98 & 3,74 & 1,00 & 4,12 & 92 \\
\hline Retirement & 49 & 4,7 & 4,02 & 1,12 & 4,28 & 84 & 3,61 & 1,09 & 3,91 & 1,13 \\
\hline Total & 384 & 100 & 3,93 & 1,07 & 4,14 & 1,08 & 3,67 & 1,03 & 4,02 & 1,01 \\
\hline $\mathbf{F}$ & & & & & & & & & & \\
\hline $\mathrm{p}$ va & & & & & & & & & & \\
\hline Fisher's LSD & hoc te & & $\begin{array}{r}\text { Reti } \\
\mathrm{O}\end{array}$ & & & & & & & \\
\hline $\mathbf{H}$ & & & & & & & & & & \\
\hline Independent var & & Factor & $\begin{array}{r}\mathrm{M} \\
\text { rela }\end{array}$ & & $\begin{array}{r}\text { Esc } \\
r\end{array}$ & $\begin{array}{l}\text { daily } \\
\text { ne }\end{array}$ & Havi & good & $\begin{array}{r}\text { Having } \\
\exp \end{array}$ & $\begin{array}{l}\text { fferent } \\
\text { nce }\end{array}$ \\
\hline Professions & $\mathrm{f}$ & $\%$ & $\overline{\mathrm{x}}$ & S.D. & $\overline{\mathrm{x}}$ & S.D. & $\overline{\mathrm{x}}$ & S.D. & $\overline{\mathrm{x}}$ & S.D. \\
\hline Officials & 126 & 32,8 & 4,37 & 86 & 3,76 & 1,25 & 4,38 &, 77 & 3,83 & 1,12 \\
\hline Self-employed people & 70 & 18,2 & 4,17 & ,99 & 3,62 & 1,26 & 4,31 & ,95 & 4,15 & ,97 \\
\hline
\end{tabular}


INTERNATIONAL JOURNAL OF ENTREPRENEURIAL KNOWLEDGE

Issue 1, volume 9, ISSN 2336-2960 (Online)

www.ijek.org

\begin{tabular}{|c|c|c|c|c|c|c|c|c|c|c|}
\hline Employees & 139 & 36,2 & 4,25 &, 84 & 3,87 & 1,10 & 4,43 & ,69 & 4,10 & ,99 \\
\hline Retirement & 49 & 4,7 & 4,12 & 1,01 & 3,81 & 1,30 & 4,53 &, 71 & 3,93 & 1,14 \\
\hline Total & 384 & 100 & 4,26 & ,90 & 3,78 & 1,20 & 4,40 & ,77 & 4,00 & 1,05 \\
\hline \multicolumn{3}{|c|}{$F$} & \multicolumn{2}{|c|}{1,262} & \multicolumn{2}{|c|}{ 687 } & \multicolumn{2}{|c|}{871} & \multicolumn{2}{|c|}{2,046} \\
\hline \multicolumn{3}{|c|}{ p value } & \multicolumn{2}{|c|}{,287 } & \multicolumn{2}{|c|}{,581 } & \multicolumn{2}{|c|}{, 456} & \multicolumn{2}{|c|}{,107 } \\
\hline \multicolumn{3}{|c|}{ Fisher's LSD post-hoc tests } & \multicolumn{2}{|c|}{ - } & \multicolumn{2}{|c|}{-} & \multicolumn{2}{|c|}{ - } & \multicolumn{2}{|c|}{-} \\
\hline \multicolumn{3}{|c|}{ H3 } & \multicolumn{2}{|c|}{ Rejected } & \multicolumn{2}{|c|}{ Rejected } & \multicolumn{2}{|c|}{ Rejected } & \multicolumn{2}{|c|}{ Rejected } \\
\hline
\end{tabular}

Anova test was performed on the recreation experience preferences scale ratings of the people from different professions group from Alanya. The results of the SPSS output matrix were shown in table 9. The $\mathrm{p}$ values of some the components of the recreation experience preferences were greater than 0.05 family togetherness, meeting new people, physical fitness, mental relaxation, escape daily routine, having good time and having a different experience and $\mathrm{H}_{3}{ }_{1}$ was rejected in these seven components of recreation experience preferences. $\mathrm{H} 3_{1}$ cannot be rejected being with friends, knowledge and skills experience, escaping family, achievement and to be where it is cooler experience dimensions of the recreation experience preferences.

$\mathbf{H 4}_{1}$ : The recreation experience preferences in Alanya is vary due to differences in residence of the people.

Table 10 Anova analysis findings related to the year of residence

\begin{tabular}{|c|c|c|c|c|c|c|c|c|c|c|}
\hline $\begin{array}{c}\text { Independent } \\
\text { variable }\end{array}$ & \multicolumn{2}{|c|}{ Factor } & \multicolumn{2}{|c|}{ Family togetherness } & \multicolumn{2}{|c|}{$\begin{array}{l}\text { Knowledge and } \\
\text { skills experience }\end{array}$} & \multicolumn{2}{|c|}{ Escaping family } & \multicolumn{2}{|c|}{ Achievement } \\
\hline Residence & $f$ & $\%$ & $\overline{\mathrm{x}}$ & S.D. & $\overline{\mathrm{x}}$ & S.D. & $\overline{\mathrm{x}}$ & S.D. & $\overline{\mathrm{x}}$ & S.D. \\
\hline Less than 3 years & 92 & 24,0 & 4,00 & 1,13 & 3,70 & 1,09 & 2,84 & 1,30 & 3,29 & 1,25 \\
\hline $3-5$ years & 42 & 10,9 & 3,66 & 1,31 & 3,71 & 1,01 & 2,42 & 1,36 & 3,30 & 1,15 \\
\hline More than 5 years & 250 & 65,1 & 4,28 & ,98 & 4,04 & ,94 & 3,02 & 1,33 & 3,70 & 1,26 \\
\hline Total & 384 & 100 & 4,14 & 1,08 & 3,92 & 1,00 & 2,91 & 1,34 & 3,56 & 1,26 \\
\hline \multicolumn{3}{|c|}{ F } & \multicolumn{2}{|c|}{7,216} & \multicolumn{2}{|c|}{4,987} & \multicolumn{2}{|c|}{3,743} & \multicolumn{2}{|c|}{4,602} \\
\hline \multicolumn{3}{|c|}{$p$ value } & \multicolumn{2}{|c|}{,001 } & \multicolumn{2}{|c|}{,007 } & \multicolumn{2}{|c|}{,025 } & \multicolumn{2}{|c|}{,011 } \\
\hline \multicolumn{3}{|c|}{ Fisher's LSD post-hoc tests } & \multicolumn{2}{|c|}{$\begin{array}{c}\text { More than } 5 \text { years }> \\
\text { Less than } 3 \text { years, } 3- \\
5 \text { years }\end{array}$} & \multicolumn{2}{|c|}{$\begin{array}{c}\text { More than } 5 \text { years }> \\
\text { Less than } 3 \text { years, } 3- \\
5 \text { years }\end{array}$} & \multicolumn{2}{|c|}{$\begin{array}{c}\text { More than } 5 \\
\text { years }> \\
3-5 \text { years }\end{array}$} & \multicolumn{2}{|c|}{$\begin{array}{c}\text { More than } 5 \text { years }> \\
\text { Less than } 3 \text { years }\end{array}$} \\
\hline \multicolumn{3}{|c|}{ H4 } & \multicolumn{2}{|c|}{ Accepted } & \multicolumn{2}{|c|}{ Accepted } & \multicolumn{2}{|c|}{ Accepted } & \multicolumn{2}{|c|}{ Accepted } \\
\hline $\begin{array}{c}\text { Independent } \\
\text { variable }\end{array}$ & \multicolumn{2}{|c|}{ Factor } & \multicolumn{2}{|c|}{$\begin{array}{c}\text { To be where it is } \\
\text { cooler }\end{array}$} & \multicolumn{2}{|c|}{$\begin{array}{l}\text { Having a different } \\
\text { experience }\end{array}$} & \multicolumn{2}{|c|}{ Being with friends } & \multicolumn{2}{|c|}{ Meeting new people } \\
\hline Residence & $f$ & $\%$ & $\overline{\mathrm{x}}$ & S.D. & $\overline{\mathrm{x}}$ & S.D. & $\overline{\mathrm{x}}$ & S.D. & $\overline{\mathrm{x}}$ & S.D. \\
\hline Less than 3 years & 92 & 24,0 & 3,78 & 1,14 & 4,04 & 1,02 & 3,85 & 1,10 & 3,54 & 1,10 \\
\hline $3-5$ years & 42 & 10,9 & 3,45 & 1,19 & 3,57 & 1,32 & 4,26 &, 85 & 3,85 & ,89 \\
\hline More than 5 years & 250 & 65,1 & 4,07 & ,98 & 4,06 & 1,00 & 4,02 & ,93 & 3,68 & 1,02 \\
\hline Total & 384 & 100 & 3,93 & 1,07 & 4,00 & 1,05 & 4,01 & ,97 & 3,67 & 1,03 \\
\hline \multicolumn{3}{|c|}{$\mathbf{F}$} & \multicolumn{2}{|c|}{7,630} & \multicolumn{2}{|c|}{3,983} & & & & \\
\hline & & & & & & & & & & \\
\hline Fisher's LS & t-hoc & & $\begin{array}{r}\mathrm{M} \\
\text { years } \\
\text { year }\end{array}$ & $\begin{array}{l}\text { an } 5 \\
\text { than } 3 \\
\text { years }\end{array}$ & More tl & years $>$ & $\begin{array}{r}\mathrm{Le} \\
\text { years }\end{array}$ & $\begin{array}{l}\text { in } 3 \\
\text { years }\end{array}$ & & \\
\hline & & & & & & & & & & \\
\hline $\begin{array}{c}\text { Independent } \\
\text { variable }\end{array}$ & & & Phy & Gitness & Menta & ration & $\begin{array}{r}\text { Esc } \\
1\end{array}$ & daily & Having & Id time \\
\hline Residence & $f$ & $\%$ & $\overline{\mathrm{x}}$ & S.D. & $\overline{\mathrm{x}}$ & S.D. & $\overline{\mathrm{x}}$ & S.D. & $\overline{\mathrm{x}}$ & S.D. \\
\hline
\end{tabular}


INTERNATIONAL JOURNAL OF ENTREPRENEURIAL KNOWLEDGE

Issue 1, volume 9, ISSN 2336-2960 (Online)

www.ijek.org

\begin{tabular}{|c|c|c|c|c|c|c|c|c|c|c|}
\hline Less than 3 years & 92 & 24,0 & 3,94 & 1,06 & 4,33 & ,92 & 3,78 & 1,13 & 4,43 & ,70 \\
\hline $3-5$ years & 42 & 10,9 & 3,88 & ,94 & 4,07 & 1,11 & 3,71 & 1,34 & 4,33 & 1,00 \\
\hline More than 5 years & 250 & 65,1 & 4,08 & 1,00 & 4,26 &, 85 & 3,80 & 1,21 & 4,41 &, 76 \\
\hline Total & 384 & 100 & 4,02 & 1,01 & 4,26 & 90 & 3,78 & 1,20 & 4,40 &, 77 \\
\hline \multicolumn{3}{|c|}{$\mathbf{F}$} & \multicolumn{2}{|c|}{1,124} & \multicolumn{2}{|c|}{1,259} & \multicolumn{2}{|c|}{,090 } & \multicolumn{2}{|c|}{,251 } \\
\hline \multicolumn{3}{|c|}{$\mathrm{p}$ value } & \multicolumn{2}{|c|}{,326 } & \multicolumn{2}{|c|}{285} & \multicolumn{2}{|c|}{,914 } & \multicolumn{2}{|c|}{,778 } \\
\hline \multicolumn{3}{|c|}{ H4 } & \multicolumn{2}{|c|}{ Rejected } & \multicolumn{2}{|c|}{ Rejected } & \multicolumn{2}{|c|}{ Rejected } & \multicolumn{2}{|c|}{ Rejected } \\
\hline
\end{tabular}

Again Anova test was performed on the recreation experience preferences scale ratings of the people from different residence group from Alanya. The results of the SPSS output matrix were shown in table 10. The $\mathrm{p}$ values of some the components of the recreation experience preferences were greater than 0.05 meeting new people, physical fitness, mental relaxation, escape daily routibe and having a good time experiemce and $\mathrm{H}_{4}$ was rejected in these five components of recreation experience preferences. $\mathrm{H}_{1}$ cannot be rejected family togetherness, knowledge and skills experience, escaping family, achievement, to be where it is cooler, having a different experience and being with friends experience dimensions of the recreation experience preferences.

H5: The recreation experience preferences in Alanya is vary due to differences in education of the people.

Table 11 Anova Analysis Findings Regarding Educational Status

\begin{tabular}{|c|c|c|c|c|c|c|c|c|c|c|}
\hline \multicolumn{2}{|c|}{ Independent variable } & \multirow{2}{*}{$\begin{array}{c}\text { Factor } \\
\%\end{array}$} & \multicolumn{2}{|c|}{$\begin{array}{c}\text { Family } \\
\text { togetherness }\end{array}$} & \multicolumn{2}{|c|}{$\begin{array}{l}\text { Being with } \\
\text { Friends }\end{array}$} & \multicolumn{2}{|c|}{ Meeting new people } & \multicolumn{2}{|c|}{$\begin{array}{l}\text { Knowledge and } \\
\text { skills experience }\end{array}$} \\
\hline Education & $\mathrm{f}$ & & $\overline{\mathrm{x}}$ & S.D. & $\overline{\mathrm{x}}$ & S.D. & $\overline{\mathrm{x}}$ & S.D. & $\overline{\mathrm{x}}$ & S.D. \\
\hline Primary school & 76 & 19,8 & 4,22 & 1,17 & 3,61 & 1,10 & 3,65 & 1,07 & 4,05 & 99 \\
\hline High school & 98 & 25,5 & 4,35 & ,91 & 4,03 & ,93 & 3,82 & 1,01 & 4,18 & 85 \\
\hline Associate Degree & 43 & 11,2 & 4,32 &, 74 & 4,20 &, 83 & 3,83 & 94 & 3,88 & ,93 \\
\hline Faculty degrees & 97 & 25,3 & 4,17 & 1,00 & 4,16 & 82 & 3,67 & 1,02 & 3,96 & 99 \\
\hline Masters degrees & 70 & 18,2 & 3,62 & 1,32 & 4,07 & 1,05 & 3,37 & 1,02 & 3,40 & 1,08 \\
\hline Total & 384 & 100 & 4,14 & 1,08 & 4,01 & 97 & 3,67 & 1,03 & 3,92 & 1,00 \\
\hline \multicolumn{3}{|c|}{ F } & \multicolumn{2}{|c|}{5,601} & \multicolumn{2}{|c|}{4,356} & \multicolumn{2}{|c|}{2,341} & \multicolumn{2}{|c|}{7,267} \\
\hline \multicolumn{3}{|c|}{ p value } & \multicolumn{2}{|c|}{,000 } & \multicolumn{2}{|c|}{,002 } & \multicolumn{2}{|c|}{,049 } & \multicolumn{2}{|c|}{,000 } \\
\hline \multicolumn{3}{|c|}{ Fisher's LSD post-hoc tests } & \multicolumn{2}{|c|}{$\begin{array}{c}\text { High school } \\
>\text { Masters degrees }\end{array}$} & \multicolumn{2}{|c|}{$\begin{array}{c}\text { Faculty } \\
\text { degrees }>\text { Primary } \\
\text { school }\end{array}$} & \multicolumn{2}{|c|}{$\begin{array}{c}\text { AssociateDegree }>\text { Masters } \\
\text { degrees }\end{array}$} & \multicolumn{2}{|c|}{$\begin{array}{l}\text { High school > } \\
\text { Masters degrees }\end{array}$} \\
\hline \multicolumn{3}{|c|}{ H5 } & \multicolumn{2}{|c|}{ Accepted } & \multicolumn{2}{|c|}{ Accepted } & \multicolumn{2}{|c|}{ Accepted } & \multicolumn{2}{|c|}{ Accepted } \\
\hline \multicolumn{2}{|c|}{ Independent variable } & Factor & \multicolumn{2}{|c|}{$\begin{array}{l}\text { Mental } \\
\text { relaxation }\end{array}$} & \multicolumn{2}{|c|}{ Escaping family } & \multicolumn{2}{|c|}{ Achievement } & \multicolumn{2}{|c|}{$\begin{array}{c}\text { To be where it is } \\
\text { cooler }\end{array}$} \\
\hline Education & f & $\%$ & $\overline{\mathrm{x}}$ & S.D. & $\overline{\mathrm{x}}$ & S.D. & $\overline{\mathrm{x}}$ & S.D. & $\overline{\mathrm{x}}$ & S.D. \\
\hline Primary school & 76 & 19,8 & 4,03 & 1,05 & 2,75 & 1,34 & 3,69 & 1,33 & 4,13 & 1,04 \\
\hline High school & 98 & 25,5 & 4,22 & ,93 & 3,26 & 1,32 & 3,90 & 1,15 & 4,09 & 1,02 \\
\hline Associate Degree & 43 & 11,2 & 4,25 &, 75 & 3,11 & 1,38 & 3,53 & 1,18 & 4,20 &, 77 \\
\hline Faculty degrees & 97 & 25,3 & 4,47 &, 72 & 2,87 & 1,31 & 3,50 & 1,26 & 3,76 & 1,13 \\
\hline Masters degrees & 70 & 18,2 & 4,27 & ,94 & 2,54 & 1,27 & 3,02 & 1,19 & 3,58 & 1,10 \\
\hline Total & 384 & 100 & 4,26 & ,90 & 2,91 & 1,34 & 3,56 & 1,26 & 3,93 & 1,07 \\
\hline \multicolumn{3}{|c|}{$\mathbf{F}$} & \multicolumn{2}{|c|}{2,579} & & & & & & \\
\hline & & & & & & & & & & \\
\hline
\end{tabular}


INTERNATIONAL JOURNAL OF ENTREPRENEURIAL KNOWLEDGE

Issue 1, volume 9, ISSN 2336-2960 (Online)

www.ijek.org

\begin{tabular}{|c|c|c|c|c|c|c|c|c|c|c|}
\hline \multicolumn{3}{|c|}{ Fisher's LSD post-hoc tests } & \multicolumn{2}{|c|}{$\begin{array}{c}\text { Faculty } \\
\text { degrees }>\text { Primary } \\
\text { school }\end{array}$} & \multicolumn{2}{|c|}{$\begin{array}{c}\text { High school } \\
>\text { Primary school }\end{array}$} & \multicolumn{2}{|c|}{$\begin{array}{c}\text { High school }>\text { Masters } \\
\text { degrees }\end{array}$} & \multicolumn{2}{|c|}{$\begin{array}{l}\text { High school }> \\
\text { Faculty degrees }\end{array}$} \\
\hline \multicolumn{3}{|c|}{ H5 } & \multicolumn{2}{|c|}{ Accepted } & \multicolumn{2}{|c|}{ Accepted } & \multicolumn{2}{|c|}{ Accepted } & \multicolumn{2}{|c|}{ Accepted } \\
\hline \multicolumn{2}{|c|}{ Independent variable } & \multirow{2}{*}{$\begin{array}{c}\text { Factor } \\
\%\end{array}$} & \multicolumn{2}{|c|}{ Physical fitness } & \multicolumn{2}{|c|}{$\begin{array}{l}\text { Escape daily } \\
\text { routine }\end{array}$} & \multicolumn{2}{|c|}{ Having good time } & \multicolumn{2}{|c|}{$\begin{array}{c}\text { Having a } \\
\text { different } \\
\text { experiences }\end{array}$} \\
\hline Education & f & & f & $\%$ & f & $\%$ & f & $\%$ & f & $\%$ \\
\hline Primary school & 76 & 19,8 & 3,98 & 1,07 & 3,57 & 1,20 & 4,22 & 1,07 & 4,03 & 1,08 \\
\hline High school & 98 & 25,5 & 4,07 & 1,00 & 3,91 & 1,18 & 4,46 &, 76 & 4,08 & 1,02 \\
\hline Associate Degree & 43 & 11,2 & 3,81 & 90 & 3,81 & 1,21 & 4,53 &, 54 & 4,11 & 1,02 \\
\hline Faculty degrees & 97 & 25,3 & 4,15 & ,96 & 3,87 & 1,20 & 4,49 &, 59 & 3,96 & 1,03 \\
\hline Masters degrees & 70 & 18,2 & 3,97 & 1,08 & 3,67 & 1,24 & 4,32 & ,71 & 3,82 & 1,12 \\
\hline Total & 384 & 100 & 4,02 & 1,01 & 3,78 & 1,20 & 4,40 & ,77 & 4,00 & 1,05 \\
\hline \multicolumn{3}{|c|}{$F$} & \multicolumn{2}{|c|}{,986 } & \multicolumn{2}{|c|}{1,163} & \multicolumn{2}{|c|}{2,019} & \multicolumn{2}{|c|}{,779 } \\
\hline \multicolumn{3}{|c|}{$\mathrm{p}$ value } & \multicolumn{2}{|c|}{,415 } & \multicolumn{2}{|c|}{,327 } & \multicolumn{2}{|c|}{,091 } & \multicolumn{2}{|c|}{,539 } \\
\hline \multicolumn{3}{|c|}{ H5 } & \multicolumn{2}{|c|}{ Rejected } & \multicolumn{2}{|c|}{ Rejected } & \multicolumn{2}{|c|}{ Rejected } & \multicolumn{2}{|c|}{ Rejected } \\
\hline
\end{tabular}

Anova test was performed on the recreation experience preferences scale ratings of the people from different education group from Alanya. The results of the SPSS output matrix were shown in table 11. The $\mathrm{p}$ values of some the components of the recreation experience preferences were greater than 0.05 physical fitness, escape daily routine, having good time and having a different experience and $\mathrm{H} 5_{1}$ was rejected in these four components of recreation experience preferences. $\mathrm{H} 5_{1}$ cannot be rejected family togetherness, being with friends, meeting new people, knowledge and skills experience, mental relaxation escaping family, achievement and to be where it is cooler dimension of the recreation experience preferences.

H6 $\mathbf{6}_{1}$ : The recreation experience preferences in Alanya is vary due to differences in age of the people.

Table 12 Anova Analysis Findings Related to Age Variable

\begin{tabular}{|c|c|c|c|c|c|c|c|c|c|c|}
\hline \multicolumn{2}{|c|}{ Independent variable } & \multirow{2}{*}{$\begin{array}{c}\text { Factor } \\
\% \\
\end{array}$} & \multicolumn{2}{|c|}{$\begin{array}{c}\text { Having a different } \\
\text { experience }\end{array}$} & \multicolumn{2}{|c|}{ Escaping family } & \multicolumn{2}{|c|}{$\begin{array}{c}\text { Mental } \\
\text { relaxation }\end{array}$} & \multicolumn{2}{|c|}{ Physical fitness } \\
\hline Age & $f$ & & $\overline{\mathrm{x}}$ & S.D. & $\overline{\mathrm{x}}$ & S.D. & $\overline{\mathrm{x}}$ & S.D. & $\overline{\mathrm{x}}$ & S.D. \\
\hline $18-25$ & 87 & 22,7 & 4,32 & 96 & 3,27 & 1,36 & 4,19 & 1,00 & 4,01 & 1,07 \\
\hline $26-33$ & 134 & 34,9 & 3,83 & 1,07 & 2,75 & 1,22 & 4,41 & ,73 & 4,16 & 87 \\
\hline $34-41$ & 87 & 22,7 & 4,09 & 1,03 & 2,93 & 1,40 & 4,24 & 91 & 3,81 & 1,12 \\
\hline $42-49$ & 50 & 13,0 & 3,82 & 1,04 & 2,78 & 1,35 & 4,00 & 1,03 & 3,94 & 1,03 \\
\hline 50 and above & 26 & 6,8 & 3,84 & 1,22 & 2,76 & 1,47 & 4,30 & 92 & 4,26 & 96 \\
\hline Total & 384 & 100 & 4,00 & 1,05 & 2,91 & 1,34 & 4,26 & ,90 & 4,02 & 1,01 \\
\hline \multicolumn{3}{|c|}{ F } & \multicolumn{2}{|c|}{3,574} & \multicolumn{2}{|c|}{2,288} & \multicolumn{2}{|c|}{2,128} & \multicolumn{2}{|c|}{2,039} \\
\hline \multicolumn{3}{|c|}{ p value } & \multicolumn{2}{|c|}{, 007} & \multicolumn{2}{|c|}{, 005} & \multicolumn{2}{|c|}{,007 } & \multicolumn{2}{|c|}{,004 } \\
\hline \multicolumn{3}{|c|}{ Fisher's LSD post-hoc tests } & \multicolumn{2}{|c|}{$\begin{array}{c}26-33>42-49,50 \text { and } \\
\text { above }\end{array}$} & \multicolumn{2}{|c|}{$\begin{array}{c}18-25>26-33,42- \\
49 \\
\end{array}$} & \multicolumn{2}{|c|}{$26-33>42-49$} & \multicolumn{2}{|c|}{$26-33>34-41$} \\
\hline \multicolumn{3}{|c|}{ H6 } & \multicolumn{2}{|c|}{ Accepted } & \multicolumn{2}{|c|}{ Accepted } & \multicolumn{2}{|c|}{ Accepted } & \multicolumn{2}{|c|}{ Accepted } \\
\hline \multicolumn{2}{|c|}{ Independent variable } & Factor & \multicolumn{2}{|c|}{$\begin{array}{c}\text { Knowledge and skill } \\
\text { experience }\end{array}$} & \multicolumn{2}{|c|}{ Being with friends } & \multicolumn{2}{|c|}{$\begin{array}{l}\text { Meeting new } \\
\text { people }\end{array}$} & \multicolumn{2}{|c|}{ Escape daily routine } \\
\hline Age & f & $\%$ & $\overline{\mathrm{x}}$ & S.D. & $\overline{\mathrm{x}}$ & S.D. & $\overline{\mathrm{x}}$ & S.D. & $\overline{\mathrm{x}}$ & S.D. \\
\hline $18-25$ & 87 & 22,7 & 4,08 & 94 & 4,18 & ,95 & 3,78 & 1,01 & 3,86 & 1,19 \\
\hline $26-33$ & 134 & 34,9 & 3,90 & 1,01 & 4,05 & 91 & 3,61 & 1,06 & 3,71 & 1,20 \\
\hline
\end{tabular}


INTERNATIONAL JOURNAL OF ENTREPRENEURIAL KNOWLEDGE

Issue 1, volume 9, ISSN 2336-2960 (Online)

www.ijek.org

\begin{tabular}{|c|c|c|c|c|c|c|c|c|c|c|}
\hline $34-41$ & 87 & 22,7 & 3,82 & 1,05 & 3,88 & ,98 & 3,59 & ,98 & 3,88 & 1,11 \\
\hline $42-49$ & 50 & 13,0 & 3,92 &, 87 & 3,88 & 1,06 & 3,68 & 1,01 & 3,68 & 1,31 \\
\hline 50 and above & 26 & 6,8 & 3,88 & 1,14 & 3,88 & 1,10 & 3,84 & 1,12 & 3,76 & 1,42 \\
\hline Total & 384 & 100 & 3,92 & 1,00 & 4,01 & 97 & 3,67 & 1,03 & 3,78 & 1,20 \\
\hline \multicolumn{3}{|c|}{ F } & \multicolumn{2}{|c|}{,755 } & \multicolumn{2}{|c|}{1,449} & \multicolumn{2}{|c|}{,654 } & \multicolumn{2}{|c|}{,437 } \\
\hline \multicolumn{3}{|c|}{ p value } & \multicolumn{2}{|c|}{,555 } & \multicolumn{2}{|c|}{217} & \multicolumn{2}{|c|}{624} & \multicolumn{2}{|c|}{,782 } \\
\hline \multicolumn{3}{|c|}{ H6 } & \multicolumn{2}{|c|}{ Rejected } & \multicolumn{2}{|c|}{ Rejected } & \multicolumn{2}{|c|}{ Rejected } & \multicolumn{2}{|c|}{ Rejected } \\
\hline \multicolumn{2}{|c|}{ Independent variable } & Factor & \multicolumn{2}{|c|}{ Family togetherness } & \multicolumn{2}{|c|}{ Achievment } & \multicolumn{2}{|c|}{$\begin{array}{c}\text { To be where it is } \\
\text { cooler }\end{array}$} & \multicolumn{2}{|c|}{ Having a good time } \\
\hline Age & f & $\%$ & $\overline{\mathrm{x}}$ & S.D. & $\overline{\mathrm{x}}$ & S.D. & $\overline{\mathrm{x}}$ & S.D. & $\overline{\mathrm{x}}$ & S.D. \\
\hline $18-25$ & 87 & 22,7 & 4,06 & ,98 & 3,80 & 1,24 & 4,06 & 1,05 & 4,48 & ,74 \\
\hline $26-33$ & 134 & 34,9 & 4,10 & 1,06 & 3,50 & 1,19 & 3,82 & 1,01 & 4,40 & 60 \\
\hline $34-41$ & 87 & 22,7 & 4,24 & 1,15 & 3,52 & 1,19 & 3,97 & 1,07 & 4,48 &, 76 \\
\hline $42-49$ & 50 & 13,0 & 4,28 & ,96 & 3,58 & 1,32 & 3,88 & 1,18 & 4,36 & ,92 \\
\hline 50 and above & 26 & 6,8 & 4,07 & 1,44 & 3,15 & 1,61 & 4,03 & 1,14 & 4,03 & 1,24 \\
\hline Total & 384 & 100 & 4,14 & 1,08 & 3,56 & 1,26 & 3,93 & 1,07 & 4,40 &, 77 \\
\hline \multicolumn{3}{|c|}{ F } & \multicolumn{2}{|c|}{,544 } & \multicolumn{2}{|c|}{1,596} & \multicolumn{2}{|c|}{,799 } & \multicolumn{2}{|c|}{1,944} \\
\hline \multicolumn{3}{|c|}{ p value } & \multicolumn{2}{|c|}{,704 } & \multicolumn{2}{|c|}{175} & \multicolumn{2}{|c|}{527} & \multicolumn{2}{|c|}{,102 } \\
\hline \multicolumn{3}{|c|}{ H6 } & \multicolumn{2}{|c|}{ Rejected } & \multicolumn{2}{|c|}{ Rejected } & \multicolumn{2}{|c|}{ Rejected } & \multicolumn{2}{|c|}{ Rejected } \\
\hline
\end{tabular}

Anova test was performed on the recreation experience preferences scale ratings of the people from different age group from Alanya. The results of the SPSS output matrix were shown in table 12. The $\mathrm{p}$ values of some the components of the recreation experience preferences were greater than 0.05 knowledge and skill experience, being with friends, meeting new people, escape daily routine, family togetherness, achievement, to be where it is cooler and having a good time and $\mathrm{H}_{1}$ was rejected in these four components of recreation experience preferences. $\mathrm{H}_{1}{ }_{1}$ cannot be rejected having a different experience, escaping family, mental relaxation and physical fitness dimension of the recreation experience preferences.

H71: The recreation experience preferences in Alanya is vary due to differences in income of the people.

Table 13 Anova analysis findings regarding monthly income status (も=Turkish Lira)

\begin{tabular}{|c|c|c|c|c|c|c|c|c|c|c|}
\hline \multicolumn{2}{|c|}{ Independent variable } & \multirow{2}{*}{$\begin{array}{c}\text { Factor } \\
\%\end{array}$} & \multicolumn{2}{|c|}{$\begin{array}{l}\text { Knowledge and } \\
\text { skills experience }\end{array}$} & \multicolumn{2}{|c|}{$\begin{array}{l}\text { Escape Daily } \\
\text { Routine }\end{array}$} & \multicolumn{2}{|c|}{ Escaping family } & \multicolumn{2}{|c|}{ Achievement } \\
\hline Income & f & & $\overline{\mathrm{x}}$ & S.D. & $\overline{\mathrm{x}}$ & S.D. & $\overline{\mathrm{x}}$ & S.D. & $\overline{\mathrm{x}}$ & S.D. \\
\hline Less than 2000 も & 123 & 32,0 & 4,13 & ,92 & 3,93 & 1,06 & 3,22 & 1,30 & 3,78 & 1,22 \\
\hline 2000-3000も & 118 & 37,7 & 4,10 & ,89 & 3,71 & 1,26 & 3,01 & 1,35 & 3,73 & 1,22 \\
\hline 3001-4000も & 107 & 27,9 & 3,57 & 1,08 & 3,85 & 1,16 & 2,55 & 1,26 & 3,23 & 1,24 \\
\hline More than 4001 も & 36 & 9,6 & 3,69 & 1,06 & 3,30 & 1,52 & 2,61 & 1,39 & 3,22 & 1,31 \\
\hline Total & 384 & 100 & 3,92 & 1,00 & 3,78 & 1,20 & 2,91 & 1,34 & 3,56 & 1,26 \\
\hline \multicolumn{3}{|c|}{ F } & \multicolumn{2}{|c|}{8,275} & \multicolumn{2}{|c|}{2,835} & \multicolumn{2}{|c|}{5,890} & \multicolumn{2}{|c|}{5,470} \\
\hline \multicolumn{3}{|c|}{$\mathrm{p}$ value } & \multicolumn{2}{|c|}{, 000} & \multicolumn{2}{|c|}{,038 } & \multicolumn{2}{|c|}{,001 } & \multicolumn{2}{|c|}{,001 } \\
\hline \multicolumn{3}{|c|}{ Fisher's LSD post-hoc tests } & \multicolumn{2}{|c|}{$\begin{array}{l}\text { Less than } 2000 \\
\text { }>2000-3000 \text { }\end{array}$} & \multicolumn{2}{|c|}{$\begin{array}{l}\text { Less than } 2000 \text { も> } \\
\text { More than } 4001 \text { }\end{array}$} & \multicolumn{2}{|c|}{$\begin{array}{l}\text { Less than } 2000 \\
\text { も } 3001-4000 \text { }\end{array}$} & \multicolumn{2}{|c|}{$\begin{array}{l}\text { Less than } 2000 \\
\text { も3001-4000 }\end{array}$} \\
\hline \multicolumn{3}{|c|}{ H7 } & \multicolumn{2}{|c|}{ Accepted } & \multicolumn{2}{|c|}{ Accepted } & \multicolumn{2}{|c|}{ Accepted } & \multicolumn{2}{|c|}{ Accepted } \\
\hline \multicolumn{2}{|c|}{ Independent variable } & Factor & \multicolumn{2}{|c|}{$\begin{array}{c}\text { To be where it is } \\
\text { cooler }\end{array}$} & \multicolumn{2}{|c|}{$\begin{array}{c}\text { Having a different } \\
\text { experience }\end{array}$} & \multicolumn{2}{|c|}{$\begin{array}{c}\text { Family } \\
\text { togetherness }\end{array}$} & \multicolumn{2}{|c|}{ Being with friends } \\
\hline Income & f & $\%$ & $\overline{\mathrm{x}}$ & S.D. & $\overline{\mathrm{x}}$ & S.D. & $\overline{\mathrm{x}}$ & S.D. & $\overline{\mathrm{x}}$ & S.D. \\
\hline
\end{tabular}


INTERNATIONAL JOURNAL OF ENTREPRENEURIAL KNOWLEDGE

Issue 1, volume 9, ISSN 2336-2960 (Online)

www.ijek.org

\begin{tabular}{|c|c|c|c|c|c|c|c|c|c|c|}
\hline Less than 2000 も & 123 & 32,0 & 4,14 &, 97 & 4,18 & ,93 & 4,20 & 1,05 & 3,89 & 1,03 \\
\hline 2000-3000も & 118 & 37,7 & 3,95 & 1,00 & 4,02 & 1,12 & 4,21 & ,95 & 4,04 & ,93 \\
\hline 3001-4000も & 107 & 27,9 & 3,70 & 1,19 & 3,82 & 1,07 & 4,12 & 1,19 & 4,10 & ,91 \\
\hline More than 4001 も & 36 & 9,6 & 3,86 & 1,09 & 3,83 & 1,10 & 3,83 & 1,20 & 4,02 & 1,05 \\
\hline Total & 384 & 100 & 3,93 & 1,07 & 4,00 & 1,05 & 4,41 & 1,08 & 4,01 &, 97 \\
\hline \multicolumn{3}{|c|}{$\mathbf{F}$} & \multicolumn{2}{|c|}{3,445} & \multicolumn{2}{|c|}{2,637} & \multicolumn{2}{|c|}{1,283} & \multicolumn{2}{|c|}{,948 } \\
\hline \multicolumn{3}{|c|}{$p$ value } & \multicolumn{2}{|c|}{,017 } & \multicolumn{2}{|c|}{,049 } & \multicolumn{2}{|c|}{280} & \multicolumn{2}{|c|}{, 418} \\
\hline \multicolumn{3}{|c|}{ Fisher's LSD post-hoc tests } & \multicolumn{2}{|c|}{$\begin{array}{l}\text { Less than } 2000 \\
\text { も>3001-4000 }\end{array}$} & \multicolumn{2}{|c|}{$\begin{array}{l}\text { Less than } 2000 \\
\text { も>3001-4000も }\end{array}$} & \multicolumn{2}{|c|}{-} & \multicolumn{2}{|c|}{ - } \\
\hline \multicolumn{3}{|c|}{ H7 } & \multicolumn{2}{|c|}{ Accepted } & \multicolumn{2}{|c|}{ Accepted } & \multicolumn{2}{|c|}{ Rejected } & \multicolumn{2}{|c|}{ Rejected } \\
\hline \multicolumn{2}{|c|}{ Independent variable } & Factor & \multicolumn{2}{|c|}{ Meeting new people } & \multicolumn{2}{|c|}{ Physical fitness } & \multicolumn{2}{|c|}{ Mental relaxation } & \multicolumn{2}{|c|}{ Having a good time } \\
\hline Income & f & $\%$ & $\overline{\mathrm{x}}$ & S.D. & $\overline{\mathrm{x}}$ & S.D. & $\overline{\mathrm{x}}$ & S.D. & $\overline{\mathrm{x}}$ & S.D. \\
\hline Less than 2000 も & 123 & 32,0 & 3,73 & ,95 & 4,14 & ,95 & 4,24 & 87 & 4,43 &, 74 \\
\hline 2000-3000も & 118 & 37,7 & 3,67 & 1,06 & 4,06 & ,96 & 4,25 & 92 & 4,43 &, 78 \\
\hline 3001-4000も & 107 & 27,9 & 3,51 & 1,04 & 3,87 & 1,12 & 4,38 &, 86 & 4,42 &, 74 \\
\hline More than 4001 も & 36 & 9,6 & 3,88 & 1,14 & 3,94 & 1,01 & 4,00 & 1,01 & 4,19 & 92 \\
\hline Total & 384 & 100 & 3,67 & 1,03 & 4,02 &, 87 & 4,26 & 90 & 4,40 &, 77 \\
\hline \multicolumn{3}{|c|}{ F } & \multicolumn{2}{|c|}{1,548} & \multicolumn{2}{|c|}{1,478} & \multicolumn{2}{|c|}{1,680} & \multicolumn{2}{|c|}{1,021} \\
\hline \multicolumn{3}{|c|}{ p value } & \multicolumn{2}{|c|}{,202 } & \multicolumn{2}{|c|}{,220 } & \multicolumn{2}{|c|}{,171 } & & \\
\hline & & & & & & & & & & \\
\hline
\end{tabular}

Again Anova test was performed on the recreation experience preferences scale ratings of the people from different income group from Alanya. The results of the SPSS output matrix were shown in table 13. The $\mathrm{p}$ values of some the components of the recreation experience preferences were greater than 0.05 family togetherness, being with friends, meeting new people, physical fitness, mental relaxation and having a good time and $\mathrm{H}_{1}$ was rejected in these six components of recreation experience preferences. $\mathrm{H} 7{ }_{1}$ cannot be rejected knowledge and skills experience, escape daily routine, escaping family, achievement, to be where it is cooler, having a different experience, family togetherness and being with friends dimension of the recreation experience preferences.

H8: There is a relationship between the recreation experience preference and location-centered satisfaction.

With the eighth question of the research, it has been tried to determine the relation between the recreational experience preferences of the local people and their level of satisfaction with the recreational areas, with Pearson correlation analysis. Correlation analysis is a statistical analysis method used to test whether there is a significant relation between at least two variables. Under correlation analysis, the relation between variables is shown with the r coefficient (Sungur, 2010: 116). However, a strong correlation is desired between variables in order to prevent a multiple correlation problem between variables (Kalayc1, 2010: 267).

Table 14 Pearson's correlation analysis

\begin{tabular}{|c|c|c|c|c|c|c|c|c|c|c|c|c|c|}
\hline Variables & F1 & F2 & F3 & F4 & F5 & F6 & F7 & F8 & F9 & F10 & F11 & F12 & LCS \\
\hline F1 & $\mathbf{1}$ & & & & & & & & & & & & \\
\hline F2 & $\begin{array}{l}.136^{* *} \\
008\end{array}$ & $\mathbf{1}$ & & & & & & & & & & & \\
\hline F3 & $\begin{array}{l}.274^{* *} \\
0.000\end{array}$ & $\begin{array}{l}.184^{* *} \\
, 000\end{array}$ & $\mathbf{1}$ & & & & & & & & & & \\
\hline F4 & $.371^{* *}$ &, $130^{*}$ &, $141^{* *}$ & $\mathbf{1}$ & & & & & & & & & \\
\hline
\end{tabular}


INTERNATIONAL JOURNAL OF ENTREPRENEURIAL KNOWLEDGE

Issue 1, volume 9, ISSN 2336-2960 (Online)

www.ijek.org

\begin{tabular}{|c|c|c|c|c|c|c|c|c|c|c|c|c|c|}
\hline & ,000 & , 011 & ,006 & & & & & & & & & & \\
\hline F5 & $\begin{array}{l}.184^{*} \\
, 000\end{array}$ & $\begin{array}{l}3315^{* *} \\
000\end{array}$ & $\begin{array}{l}, 222^{* *} \\
000\end{array}$ & $\begin{array}{l}, 033 \\
, 521 \\
\end{array}$ & 1 & & & & & & & & \\
\hline F6 & $\begin{array}{l}, 402^{* *} \\
, 000\end{array}$ & $\begin{array}{l}281^{* *} \\
000\end{array}$ & $\begin{array}{l}155^{* *} \\
002\end{array}$ & $\begin{array}{l}355^{* *} \\
, 000\end{array}$ & $\begin{array}{l}1141 * * \\
006 \\
, 006\end{array}$ & 1 & & & & & & & \\
\hline F7 & $\begin{array}{l}, 134^{* *} \\
008\end{array}$ & $\begin{array}{l}, 272^{* *} \\
000\end{array}$ & $\begin{array}{l}430^{* *} \\
000\end{array}$ & $\begin{array}{l}, 141^{*} \\
, 006\end{array}$ & $\begin{array}{l}163^{* *} \\
001\end{array}$ & $\begin{array}{l}, 182^{* *} \\
000\end{array}$ & 1 & & & & & & \\
\hline F8 & $\begin{array}{l}, 112^{*} \\
, 028\end{array}$ & $\begin{array}{l}331 * * \\
, 000 \\
\end{array}$ & $\begin{array}{l}186^{* *} \\
, 000 \\
\end{array}$ & $\begin{array}{l}, 261^{*} \\
000 \\
\end{array}$ & $\begin{array}{l}1196^{*} \\
, 000\end{array}$ & $\begin{array}{l}174^{* *} \\
001 \\
\end{array}$ & $\begin{array}{l}456^{* *} \\
000 \\
\end{array}$ & 1 & & & & & \\
\hline F9 & $\begin{array}{l}, 243^{* *} \\
000 \\
\end{array}$ & $\begin{array}{l}126^{*} \\
, 013 \\
\end{array}$ & $\begin{array}{l}, 355^{* *} \\
, 000 \\
\end{array}$ & $\begin{array}{l}, 221 * * \\
, 000 \\
\end{array}$ & $\begin{array}{l}168^{* *} \\
, 001 \\
\end{array}$ & $\begin{array}{l}, 119^{*} \\
, 020 \\
\end{array}$ & $\begin{array}{l}156^{* *} \\
002 \\
\end{array}$ & $\begin{array}{l}1,129 * \\
, 011 \\
\end{array}$ & 1 & & & & \\
\hline F10 & $\begin{array}{l}, 086 \\
091\end{array}$ & $\begin{array}{l}, 240 * * \\
, 000\end{array}$ & $\begin{array}{l}, 182^{*} \\
, 000\end{array}$ & $\begin{array}{l}, 182^{* *} \\
, 000\end{array}$ & $\begin{array}{l}, 416^{* *} \\
000\end{array}$ & $\begin{array}{l}, 107 * \\
, 037\end{array}$ & $\begin{array}{l}, 258^{* *} \\
, 000\end{array}$ & $\begin{array}{l}, 411 * * \\
, 000\end{array}$ & $\begin{array}{l}, 115^{*} \\
, 024\end{array}$ & 1 & & & \\
\hline F11 & $\begin{array}{l}\text {,250** } \\
, 000\end{array}$ & $\begin{array}{l}, 277^{* *} \\
000\end{array}$ & $\begin{array}{l}108^{*} \\
, 034\end{array}$ & $\begin{array}{l}., 373^{* *} \\
000\end{array}$ & $\begin{array}{l}176^{* *} \\
001\end{array}$ & $\begin{array}{l}, 305^{* *} \\
000\end{array}$ & $\begin{array}{l}, 269 * * \\
, 000\end{array}$ & $\begin{array}{l}, 453^{* *} \\
, 000\end{array}$ & $\begin{array}{l}, 151^{* *} \\
003\end{array}$ & $\begin{array}{l}, 254^{*} \\
, 024\end{array}$ & 1 & & \\
\hline F12 & $\begin{array}{l}, 090 \\
, 077\end{array}$ & $\begin{array}{l}, 086 \\
, 093\end{array}$ & $\begin{array}{l}-, 053 \\
, 301\end{array}$ & $\begin{array}{l}, 268^{* *} \\
000\end{array}$ & $\begin{array}{r}, 049 \\
, 343\end{array}$ & $\begin{array}{l}156^{* *} \\
002\end{array}$ & $\begin{array}{l}, 071 \\
, 167\end{array}$ & $\begin{array}{l}176^{* *} \\
, 001\end{array}$ & $\begin{array}{l}, 188^{* *} \\
000\end{array}$ & $\begin{array}{l}, 163^{*} \\
003\end{array}$ & $\begin{array}{l}, 324 * * \\
, 000\end{array}$ & 1 & \\
\hline LCS & $\begin{array}{l}, 069 \\
, 178\end{array}$ & $\begin{array}{l}, 077 \\
, 130\end{array}$ & $\begin{array}{l}, 015 \\
, 767\end{array}$ & $\begin{array}{l}, 041 \\
, 026\end{array}$ & $\begin{array}{l}156^{* *} \\
, 002\end{array}$ & $\begin{array}{l}, 076 \\
, 137\end{array}$ & $\begin{array}{l}, 094 \\
066\end{array}$ & $\begin{array}{l}, 014 \\
, 780\end{array}$ & $\begin{array}{l}, 120^{*} \\
, 019\end{array}$ & $\begin{array}{l}, 060 \\
, 237\end{array}$ & $\begin{array}{l}, 021 \\
, 679\end{array}$ & $\begin{array}{l}053 \\
, 296\end{array}$ & 1 \\
\hline
\end{tabular}

In table 14, a Pearson's correlation was run to determine the relationship between mental relaxation (F3) and physical Fitness (F7) values. There was a strong, positive correlation between f3-mental relaxation and $\mathrm{f} 7$-physical Fitness $(r=, 430 ; \mathrm{p}=0,00<0,05)$. Then, a Pearson's correlation was run to determine the relationship between f8-knowledge and skills experience and satisfaction values. There was a weak, positive correlation between f8-knowledge and skills experience and satisfaction values ( $r=, 156$; $\mathrm{p}=0,02<0,05) . \mathrm{H} 8_{1}$ was accepted.

H91: Recreation experience preferences positively affect location-centered satisfaction.

With the nineth hypothesis of the research, it has been tried to measure with multiple regression analysis the effect of the recreational experience preferences of the local people on their level of satisfaction with the recreational areas. Regression analysis is an analysis method that allows to find the cause and effect relation between variables. It is possible to measure with this analysis the effect of multiple independent variables on a dependent variable. While F statistic is used to test the significance of the model as a whole, $\mathrm{t}$ statistic is used to test whether variables are separately significant or not. Beta $(\beta)$ value shows the order of importance of independent variables. The variable that has the highest Beta value and the $t$ value of which is significant is relatively the most important variable (Kalayc1, 2010: 259-269). In the regression analysis of this research, the independent variables comprise recreational experience preferences (twelve elements) and the dependent variable comprises the location-centered satisfaction scale.

\section{Table 15 Regression Analysis Findings Related to Location-Centered Satisfaction}

\begin{tabular}{|c|c|c|c|c|c|c|c|c|}
\hline $\begin{array}{c}\text { Independent Variables } \\
\text { (Recreation Experience Preferences (REP) } \\
\text { Scale Domain) }\end{array}$ & B & $\beta$ & $\begin{array}{c}\text { t- } \\
\text { value }\end{array}$ & $\begin{array}{c}\mathrm{p}- \\
\text { value }\end{array}$ & $\begin{array}{c}\text { Adjusted } \\
\mathbf{R}^{2}\end{array}$ & $\mathbf{R}^{2}$ & F & p. \\
\hline Constant & 1,858 & - & 4,911 &, 000 & \multirow{13}{*}{,213 } & \multirow{13}{*}{,228 } & \multirow{13}{*}{1,691} & \multirow{13}{*}{,027 } \\
\hline F1-Having a good things & ,027 &, 022 & 366 &, 714 & & & & \\
\hline F2-Family togetherness & 019 &, 022 &, 380 & ,704 & & & & \\
\hline F3-Mental relaxation &,- 113 &,- 108 & $-1,752$ & ,801 & & & & \\
\hline F4-Having a different experience & ,012 & 054 & 227 & ,820 & & & & \\
\hline F5-Being with Friends & ,241 & ,231 & 2,476 & ,014 & & & & \\
\hline F6-To be where it is cooler &, 035 &, 040 & ,668 &, 504 & & & & \\
\hline F7-Physical Fitness &,- 115 & ,124 & 1,978 & ,049 & & & & \\
\hline F8- Knowledge and skills experience &,- 062 &,- 066 & $-1,002$ & ,317 & & & & \\
\hline F9-Escape Daily Routine & ,086 &, 110 & 1,944 &, 053 & & & & \\
\hline F10-Meeting new people &,- 003 &,- 004 &,- 061 & ,952 & & & & \\
\hline F11-Achievement &,- 037 &,- 049 &,- 783 &, 434 & & & & \\
\hline F12-Escaping family & ,019 &, 022 & ,380 & ,704 & & & & \\
\hline
\end{tabular}

When the multiple linear regression results provided in table 15 are examined, it is observed that the model is significant at every level $(\mathrm{F}=1.691 ; \mathrm{p}=0.027<0.05)$. The parameter value for the being with 


\section{INTERNATIONAL JOURNAL OF ENTREPRENEURIAL KNOWLEDGE}

Issue 1, volume 9, ISSN 2336-2960 (Online)

www.ijek.org

friends experience is .241. An increase of one unit related to the being with friends experience increases the satisfaction with recreational areas by .241 unit. However, the parameter value for the improving physical health experience is -.115. A decrease of one unit related to the physical health experience decreases the satisfaction with recreational areas by -.115 unit. When Beta comparisons of the parameters with significant $t$ values are considered, the being with friends experience is more important $(\beta=.231)$ than the improving physical health experience $(\beta=.124)$. Finally, the independent variables' level of explaining the dependent variable is statistically significant (Adjusted $\mathrm{R}^{2}=.213$ ). In other words, the independent variables explain the dependent variable at a rate of $21 \%$. $\mathrm{H} 9{ }_{1}$ was accepted.

\section{DISCUSSION}

Recreational activities have health and social benefits for people. This study aims to determine recreational experience preferences of the local people in Alanya, their leisure constraints, their expectations for recreational activities from the local authority, and the level of their satisfaction with recreational areas. The majority of the local people perform recreational activities outdoor, for 1-2 hours, in the evening, with their friends, and in July (52.1\%). According to Johnson et al., (2001: 111-133), people perform outdoor recreation activities in natural areas, parks or more domestic places such as gardening. However, most of the research participants spend less than two hours in recreational areas. According to Nadirov (2017: 127), the most important reason why people participate in recreational activities for a short time may be due to reasons such as the desire to experience a feeling of relaxation, love of nature, work and family life. Opportunities for access to recreation centers and the sustainability of their activities in these areas should be offered to people by local authority. Therefore, especially, it is necessary to focus on people in different parts of the city and to establish management strategies based on the number of visitors in the region. This will enable recreational areas to fulfill their goals and duties completely, especially during the pandemic period (Covid-19).

The majority of the participants prefer going on a picnic and visiting friends. However, it has been determined that the majority of the local people do not participate in recreational activities due to lack of leisure time, not enough money, and pollution of toilets, fountains and wash-hand basins in the region. And, the majority of the participants expect from the local authority construction of new areas, ensuring that everyone benefits from recreational facilities, cleaning of areas, and organizing events with artistic value. Determining the number of visitors coming to recreational areas contributes to the determination of the cleaning and disinfection frequency of these areas (Girma et al., 2019: 149). Visiting urban parks can significantly improve overall health and assist in meeting individuals' social interaction needs. Although residents have reduced the frequency of visits during the pandemic, even once a week can be beneficial (Xie et al., 2020: 10). Therefore, the fact that local authorities build small parks that almost everyone can reach in the city center, especially during the pandemic period, will positively affect the mental and physical health of people.

Considering the findings regarding the recreation experience preferences of the local people, it is seen that the experiences of having a good time and relaxing mentally have the highest average. In city planning, local authority should distribute the parks from which people can temporarily move away from the responsibilities of daily life to different parts of the city and make their city plans considering the natural habitats. Natural habitats contribute to reducing the stress and fatigue that people have (Kaplan, 2007: 17).

Stress cause trivial problems such as misfit characters and disagreements in workplace to become more serious ones. Also, stress leads to severe social and health problems like depression, obesity, diabetes, and suicides. A number of studies on this subject revealed that recreational experiences have health benefits resulting from both active and passive recreation opportunities; and that thinking over past 


\section{INTERNATIONAL JOURNAL OF ENTREPRENEURIAL KNOWLEDGE}

Issue 1, volume 9, ISSN 2336-2960 (Online)

www.ijek.org

experiences like exercise, physical activity, and outdoor recreation have positive effect on depression, stress and self-confidence (Kurar, 2020: 710). Studies indicate that people in quarantine are more prone to developing various symptoms of psychological disorders, such as stress, depression, emotional fatigue, and insomnia (Fofana et al., 2020: 291). A study from Italy reported that more than half of its respondents reported different degrees of depression, anxiety, and stress during the urban quarantine period (Mazza et al., 2020: 31-69).

In this research, the satisfaction level of the local people from the recreational areas in the destination was found very low. Therefore, local authorities should build parks accessible to almost everyone in the city center, and they should appeal to local people of almost all age groups by building swimming pools, cycling-walking paths and ponds / pools. According to Arslan and Türkmen (2012: 45), leisure and recreation activities have an important place in solving many problems in city life and even preventing the problems in advance. According to the results obtained, depending on the characteristics of the place where people live, the time they spend in their recreational activities is determinant on their satisfaction.

Traditions, habits and the individual's sensitivity to social values, especially social roles and situations, prevent the use of leisure time as desired in traditional societies that are determined depending on age and gender. According to Meyer et al., (2002:292-295), gender differences females being more intrinsically motivated while males were more extrinsically motivated. In this study female participants desire to live dimension of the recreation experience preferences more than the male participants. It was revealed that the recreation experience preferences of people in Alanya is vary due to differences in gender level of the people being with friends, meeting new people, knowledge and skills experience, physical fitness, escaping family, achievement, having a different experience and having good time experience dimension of the recreation experience preferences. $\mathrm{H} 1_{1}$ was accepted in these eight components of recreation experience preferences.

Participating in or doing leisure activities with the family in outdoor or indoor recreation areas was found very rewarding in terms of strengthening family ties. In other words, it is indicated that spending/sharing leisure time with the family affects personal and social development (Mahon vd., 2000: 25-34). It was revealed that the recreation experience preferences of people in Alanya is vary due to differences in marital status level of the people being with friends, meeting new people, achievement and having a different experience dimensions of the recreation experience preferences. However single participants desire to live dimension of the recreation experience preferences more than the married participants. $\mathrm{H} 2_{1}$ was accepted.

Terms such as working time and time remaining from work are concepts for the modern era. Employees live constantly under pressure in terms of time efficiency (Torkildsen, 1986: 86). With the industrialization, doing many works through machines decreases the working times, while increasing times remaining from work. This situation has also revealed concepts such as early retirement (Kraus, 1998: 186-188). In this study, the retirement participants want to being with friends and escaping family more than the other participants. Besides, employees participants want to desire knowledge and skill, achievement and to be where it is cooler more than the other participants. $\mathrm{H} 3_{1}$ was accepted. As is seen, recreation activities both provide socialization opportunities and make elders active in the society. So, it prevents social isolation.

Increasing the remaining time due to the reduction of working hours facilitates the participation of people in leisure time activities for longer periods. Because, the distance to recreational areas is determinant in participation in leisure activities. In other words, shorter distances to the place of residence or areas where more time can be spent may be preferred (Jensen, 1995: 33). Accordingly, the more than 5 years resident desire to live the family togetherness, knowledge and skills experience, escaping family, achievement, to be where it is cooler and having a different experience more than the other participants. Besides, the 3-5 


\section{INTERNATIONAL JOURNAL OF ENTREPRENEURIAL KNOWLEDGE}

Issue 1, volume 9, ISSN 2336-2960 (Online)

www.ijek.org

years resident desire to being with friends more than the other participants. $\mathrm{H}_{1}$ was accepted. As can be seen in the results of this research, the recreation experience preferences of those who reside in the destination for medium and long term differ. Destination planners and policy makers should plan recreational areas in order to the length of stay of local residents in the destination. Especially during the pandemic period, building areas where people can spend time even for a short time will contribute to their socialization.

The increase in the education level of people also arouses their interest in different activities (Godbey, 1999: 12). Participation actively in recreational activities develops youth, increases their education and prevents bad habits (Estes and Henderson, 2003: 22-31). The high school group desire to knowledge and skills experience, escaping family and achievement more than the other groups. Besides, the associate degree group desire to live the being with friends, meeting new people and to be where it is cooler more than the other groups. On the other hand, the primary school group desire to family togetherness and mental relaxation more than the other groups. $\mathrm{H} 5_{1}$ was accepted. In a research conducted in this context, it was obtained that students in schools applying an environment-based (recreational area / green area) learning model got higher scores in exams than students in other schools (Mann and Hensley, 2002: 6).

18-25 desire to live the having a different experience and escaping family more than the other groups. Besides, 26-33 desire to mental relaxation experience than the other groups. H6 ${ }_{1}$ was accepted. Recreational activities offer important opportunities for people in this age group to solve their problems and integrate with the society. In addition, the habits gained at this age are the determinants of the recreation experience preference in later ages. Accordingly, plans should be made for the needs and characteristics of the later age group in terms of recreational activities.

Those with a monthly net income below 2000 ₹ desire to experience more than knowledge and skills experience, escape daily routine, escaping family, achievement, to be where it is cooler, having a different experience, family togetherness and being with friends than other income groups. H7 1 was accepted. According to Wichasin (2007: 26), the increase in people's income levels concludes more participation in leisure activities. But, in cases where people participate in recreational activities, expenses such as entrance fees of facilities, equipment and transportation costs are determinant (Torkildsen, 1986: 96). Considering the averages of the highest income group in this research, it is seen that it is lower than the other group averages. Therefore, more and wide varity of activities should be offered to people in the high income group.

Results also showed some significant correlations between motivational dimensions and locationsentered satisfaction (LCS) dimensions. This suggests that the recreation professional may consider learning from activity and being with friends, physical fitness and avoiding daily routine in the recreational area choice. According to the regression analysis, being with friends increases satisfaction with recreation areas. However, a one-unit reduction, depending on the physical health experience, reduces satisfaction from recreational areas. To meet visitors' needs and optimize their satisfaction, managers must be able to identify the motivations driving visitors to recreation areas (Graefe et al. 2000: 107).

\section{CONCLUSIONS AND RECOMMENDATIONS}

This study aims to determine recreational experience preferences of the local people in Alanya, their leisure constraints, their expectations for recreational activities from the local authority, and the level of their satisfaction with recreational areas. As a result of the analyses made within this scope, the majority of the participants are male, married, 26-33 years old, worker, high-school or associate degree program graduate, included in the low-income group, and have resided in the destination for a long time. However, 


\section{INTERNATIONAL JOURNAL OF ENTREPRENEURIAL KNOWLEDGE}

Issue 1, volume 9, ISSN 2336-2960 (Online)

www.ijek.org

the majority of the participants spend 1-2 hours in average daily in outdoor recreational areas and recreative areas.

When the distributions related to the type of participation in leisure time activities are observed, the majority of the participants spend time with their friends. In addition, the majority of the participants perform recreational activities in the evening and in July. It has been determined that the most preferred recreational activities of the participants are going on a picnic, visiting friends, and internet surfing. Shopping is perceived as a leisure activity, the source of fun and excitement. Our results fit opinion of Krbová (2016:50). The majority of the local people do not participate in recreational activities due to lack of leisure time. Our results fit opinion of Johnson et al. (2001: 127).

The participants performed their outdoor recreational activities mostly in natural areas, parks or more domestic places such as gardens. For this reason, it is required for the local authority to provide opportunities for access to recreation centers and the sustainability of the activities in those areas. In other words, it is necessary to carry out studies for increase of the awareness in the protection of natural areas by the local authority.

It is important to determine the basic needs that motivate people for recreational activities or that lead people to participate in such events. Therefore, the local authority should carry out studies to remove highly structural constraints related to these areas. On the other hand, all the people should benefit from the recreative events. However, the local authority should be attentive to protect the natural habitat, cultural heritage, and environment while satisfying the expectations of the people for the recreational areas.

People are motivated for recreational areas by their different experience preferences. For this reason, during the national and regional planning of recreational areas, it is necessary to take into account the importance of leisure time activities and of the psychological factors that lead people to such activities. Thus, the local authority may contribute to personal and social development through recreation. According to the findings of this research, the experience of being with friends and the desire to have an experience of improving physical health were determined as the two most important motivational tools that direct people to recreational activities.

The recreational experience preferences of people are closely associated with their gender and marital status. Therefore, gender and marital status of people should be taken into consideration while planning recreational areas. In addition, the economic welfare and professions of people differentiate their motivations for recreational activities. For this reason, the local authority should create areas where almost each income and profession group may spend time, and popularize more the reactive areas. However, Ryan (1995:79-94) found that females were more likely than males to be motivated by mental and physical relaxation, and a desire to develop close personal relationships when traveling. Our results fit opinion of Ryan (1995:79-94). In this direction, recreational areas such as the observation terrace walking path, waterslide along Dim River Valley, turfskiing to the appropriate hillsides will contribute to the attractiveness of the region and the people to spend quality leisure time.

The people's duration of residence in the destination differentiate their recreational experience preferences. Therefore, the local authority should take care to organize events intended in order for the people to know each other and make friends. Thus, the foreignness, fear, and isolation obstacles, if any, in the destination may be removed through recreation. Informing almost everyone about the activities organized by local authorities will increase the rate of participation in the activities. Thus, it may be contributed to the increase of the life quality of those who desire to get to know new people, have a good time and depart from responsibilities of daily life. 


\section{INTERNATIONAL JOURNAL OF ENTREPRENEURIAL KNOWLEDGE}

Issue 1, volume 9, ISSN 2336-2960 (Online)

www.ijek.org

Educational level of the people brings along their interest in different activities. Therefore, the local authority should take into consideration the educational level of the people while planning recreational areas. It is highly important to determine early the interests and talents of both adults and children through recreation in order to direct their education.

It has been determined that the local people visiting the recreational areas in the destination generally do not leave the recreational areas satisfied. The prerequisite for ensuring the intent of the local people for visiting recreational areas again is to ensure their general satisfaction. For this reason, the local authority organizations and businesses should determine and analyze the factors causing dissatisfaction of the local people, and to carry out studies to remove such factors.

A regression analysis was conducted aiming to establish the link between motivation (dimensions) and Location-Centered Satisfaction. The independent variables' level of explaining the dependent variable is statistically significant. According to the regression analysis, being with friends increases satisfaction with recreation areas. However, a one-unit reduction, depending on the physical health experience, reduces satisfaction from recreational areas. The independent variables explain the dependent variable at a rate of $21 \%$.

In this research, the motivations that were selected, similar with the research made by Manfredo et al. (1996: 188-213) and Lee et al. (2002: 18-37), from the list of Driver (1983: 1-10) that includes 19 motivation and 320 items were preferred. However, it is known that there are variables, other than those used in this research, on the satisfaction with the recreational areas. Motivations that lead people to perform recreational activities may be identified through different motivation sizes that can be determined by researchers from the recreational experience preferences list of Driver (1983: 1-10).

In this study, just the situation of the local people was examined. However, there are also resident foreigners in this destination. On that sense, the leisure time habits of the local people and resident foreigners in the destination should be examined in another research.

Furthermore, children aged 18 and under are not included in the research sample because they are students at the destination. On the other hand, recreational activities during their student years make it easier for them to start their profession. For this reason, the relationship between students' recreational experience preferences and profession preferences should be studied as another research topic.

\section{REFERENCES}

Ashby, J. S., \& Rice, K. G. (2002). Perfectionism, Dysfunctional Attitudes, and Self-Esteem: A Structural Equations Analysis. Journal of Counseling and Development, 80 (1), 197-203.

Ateca-Amestoya, V., Serrano-del-Rosala, R. \& Vera-Toscanoa, E. (2008). The Leisure Experience. Journal of Socio-Economics, 37(1), 64-78.

Baş, T. (2006). Anket [Survey]. Ankara: Seçkin Yayıncıllk.

Broadhurst, R. (2001). Managing Environments for Leisure and Recreation. UK: GBR Roudledge.

Brown, P. J. \& Haas, G. E. (1980). Wilderness Recreation Experience: The Rawah Case. Journal of Leisure Research, 12(3), 229-241.

Butler, G. (1968). An Introduction to Community Recreation. London.

Butler, S. (Ed.). (2013). Macquarie Dictionary. Australia: Macquarie Dictionary Publishers.

California Outdoor Recreation Planning Program [CORP] (2005). An Element of the California Outdoor Recreation Planning Program. The Health and Social Benefits of Recreation State of California Resources Agency, California. 


\section{INTERNATIONAL JOURNAL OF ENTREPRENEURIAL KNOWLEDGE}

Issue 1, volume 9, ISSN 2336-2960 (Online)

www.ijek.org

Cummings, I. E. (2008). The Vigorous Mind: Cross-train Your Brain to Break Through Mental, Emotional, and Professional Boundaries. Health Communications, Inc.

De Grazia, S. (1962). Of Time, Work, and Leisure. Twentieth Century Fund, New York.

Ditton, R., Loomis, D. \& Choi, S. (1992). Recreation Specialization: Re-Conceptualization from a Social Worlds Perspective. Journal of Leisure Research, 24 (1), 33-40.

Driver, B. L. (1976). Toward a Better Understanding of the Social Benefits of Outdoor Recreation Participation. North Carolina, US: General Technical RDTort SE-9.

Driver, B. L. (1983). Master List of Items for Recreation Experience Preference Scales and Domains. Unpublished Document. US: Fort Collins.

Driver, B. L. \& Brown, P. J. (1975). A sociopsychological definition of recreation demand, with implications for recreation resource planning. US: In Assessing Demand for Outdoor Recreation.

Driver, B. L. \& Knopf, R. C. (1977). Personality, outdoor recreation and expected consequences. Environment and Behavior, 9 (2), 169-193.

Driver, B. L. \& Tocher, S. R. (1970). Toward a Behavioral Interpretation of Recreation Engagements with Implications For Planning. In B.L. Driver (Ed.), Elements of Outdoor Recreation Planning. US: Ann Arbor.

Dumazedier, J. (1974). "Leisure and the social system”. J. F. Murphy (Ed.). Concepts of Leisure, PrenticeHall, Englewood Cliffs, NJ, s. 133-145.

Estes, C. ve Henderson, K. (2003). "Enjoyment and the Good Life.” Parks and Recreation, 38 (2), 22-3 1.

Fofana, N. K., Latif, F., Sarfraz, S., Bashir, M. F., \& Komal, B. (2020). Fear and agony of the pandemic leading to stress and mental illness: an emerging crisis in the novel coronavirus (COVID-19) outbreak. Psychiatry Research.

Fornell, C., \& Larcker, D. F. (1981). Evaluating structural equation models with unobservable variables and measurement error. Journal of Marketing Research 18 (1), 39-50.

Girma, Y., Terefe, H., Pauleit, S., \& Kindu, M. (2019). Urban green spaces supply in rapidly urbanizing countries: The case of Sebeta Town, Ethiopia. Remote Sensing Applications: Society and Environment, 13: 138-149.

Giuliani, M. V. \& Feldman, R. (1993). Place Attachment in a Developmental and Cultural Context Human Behavior and Environment. Advances in Theory and Research, 12 (1), 269-270.

Godbey, G. (1999). Leisure in Your Life: Ane Explanation. 2nd edition. Venture Publishing Inc., Pennsylvania.

Goodale, T. \& Witt, P. (1980). Recreation and Leisure: Issue in an Era of Change: Pennsylvania. US: Venture Publishing Inc.

Haywood, L., Kew, F. \& Bramham, P. (1989). Understanding Leisure. US: Nelson Thornes.

Hacıoğlu, N., Gökdeniz, A. ve Dinç, Y. (2015). Boş Zaman ve Rekreasyon Yönetimi: Örnek Animasyon Uygulamalar1 [Leisure and recreation management: Sample animation applications]. Detay Yayincilik, Ankara.

Halemba, P., \& Kucharski, M. (2014). Sports volunteering as an element which gives advantage with employment in organisations operating in the field of sport and recreation. Polish Journal of Management Studies, 9, 34-42.

Hazar, A. (2014). Rekreasyon ve Animasyon [Recreation and animation]. 4 .Bask1, Ankara: Detay Yayincilik.

Jankiewicz, J. (2015). Time allocation of people not working in the market: how does unemployment differ from economic inactivity in Central Eastern Europe. Journal of International Studies, 8(3), 201-209.

Jensen, C. R. (1995). Outdoor Recreation in America. Fifth Edition, Human, Kinetics, USA.

Johnson, C. Y., Bowker, J. M., \& Cordell, H. K. (2001). Outdoor recreation constraints: An examination of race, gender, and rural dwelling. Journal of Rural Social Sciences, 17(1): 111-133.

Kalaycı, Ş. (2010). Faktör Analizi [Factor analysis]. Ş. Kalaycı (Ed.). SPSS Uygulamalı Çok Değişkenli Istatistik Teknikleri. (s. 321-331). Ankara: Asil Yayın Dağıtım. 


\section{INTERNATIONAL JOURNAL OF ENTREPRENEURIAL KNOWLEDGE}

Issue 1, volume 9, ISSN 2336-2960 (Online)

www.ijek.org

Kelly, J. R. \& Freysinger, V. J. (2000). 21st century leisure: Current issues. US: Allyn \& Bacon.

Kibler, A. M. \& Smith, R. W. (2000). Leisure Needs and Leisure Satisfaction Levels of Adult Males with HIV and AIDS. Therapeutic Recreation Journal, 200(34), 120-140.

Knopf, R. C., Driver, B. L. \& Bassett, J. R. (1973). Motivations for Fishing. In Transactions of the 28th North American Wildlife and Natural Resources Conference, US: Wash DC: Wildlife Management Institute.

Kraus, R. G. (2001). Recreation and Leisure in Modern Society. US: Jones \&Bartlett, Sudburry.

Kraus, R. G. (1998). Leisure in a changing America: Multicultural perspectives. Macmillan College, New York.

Kuo, C. T. (2011). A study on participation motivation in exercise, leisure constraints, life quality, and job satisfaction of joggers-a case of joggers in Chiayi county and city. Journal of Global Business Management, 7(2), 1-2.

Kurar, İ. (2019). Halkın Rekreasyon Deneyim Tercihi: Alanya Dim Çayı Vadisi Örneği, People's Recreation Experience Preference: The Case of Alanya Dim River Valley] 3. Uluslar aras1 Turizmin Geleceği; İnovasyon, Girişimcilik ve Sürdürebilirlik Kongresi, [The Third International Congress on Future of Tourism: Innovation, Entrepreneurship and Sustainability (Futourism 2019)], Mersin University, Mersin.

Lee, J. H., Scott, D. \& Moore, R. L. (2002). Predicting Motivations and Attitudes of Users of a Multiuse Suburban Trail. Journal of Park and Recreation Administration, 20 (3), 18-37.

Lloyd, K. \& Auld, C. (2002). Social Indicators Research: An International and Interdisciplinary. Journal for Quality-of-Life Measurement, 57 (1), 43-71.

Lu, L. \& Hu, C. H. (2005). Personality, Leisure Experiences and Happiness. Journal of Happiness Studies, 6 (3), 325-342.

Manfredo, M. J., Driver, B. L. \& Tarrant, M. A. (1996). Measuring Leisure Motivation: A Meta-Analysis of the Recreation Experience Preference Scales. Journal of Leisure Research, (28), 188-213.

Mazza, C., Ricci, E., Biondi, S., Colasanti, M., Ferracuti, S., Napoli, C., \& Roma, P. (2020). A nationwide survey of psychological distress among Italian people during the COVID-19 pandemic: immediate psychological responses and associated factors. International journal of environmental research and public health, 17(9), 31-65.

Meyer, L., Thapa, B. \& Pennington-Gray, L. (2002). An Exploration of Motivations among Scuba Divers in North Central Florida. Proceedings of the 2002 Northeastern Recreation Research Symposium, 292-295.

Mclean, D. \& Hurt, A. (2015). Kraus' Recreation and Leisure in Modern Society. (Tenth Edition). US: Jones \& Bartlett Publishers.

Mieczkowski, Z. (1990). World Trend in Tourism and Recreation. US: Peter Lang Publishing.

Nadirov, O., Aliyev, K., Dehning B. (2017). To Work More or Less? The Impact of Taxes and Life Satisfaction on the Motivation to Work in Continental and Eastern Europe. Economics and Sociology, 10(3), 266-280.

Nakip, M. (2006). Pazarlama Araştırmaları Teknikleri ve (SPSS Destekli) Uygulamalar. Seçkin Kitapevi, Ankara.

Özdağ, S., Yeniçeri, M., Fişekçioğlu, İ. B., Akçakoyun, F. ve Kürkçü, R. (2009). Devlet Memurlarının Boş Zaman Değerlendirme Eğilimleri, Antropometrik ve Fiziksel Uygunluk Seviyeleri [Recreational Time Evaluatıon Tendencies, Antropometric and Physical Fitness Level of Civil Servants]. Selçuk Üniversitesi Sosyal Bilimler Enstitüsü Dergisi [Selçuk University The Journal of Institute of Social Sciences], (22), 307-323.

Özdamar, K. (2003). Modern Bilimlerde Araştırma Yöntemleri [Research Methods in Modern Sciences]. Eskişehir: Kaan Kitabevi.

Payne, L. L., Mowen, A. J. \& Orsega-Smith, E. (2002). An Examination of Park Preferences and Behaviors Among Urban Residents: The Role of Residential Location, Race and Age. Leisure Sciences: An Interdisciplinary Journal, 24(2), 181-198.

Kaplan, M. (1975). Leisure: Theory and Practice. John Wiley, New York. 


\section{INTERNATIONAL JOURNAL OF ENTREPRENEURIAL KNOWLEDGE}

Issue 1, volume 9, ISSN 2336-2960 (Online)

www.ijek.org

Krbová, P. K. (2016). Generation Y attitudes towards shopping: a comparison of the Czech Republic and Slovakia. Journal of Competitiveness, 8(1): 38-54.

Mann, L. and Hensley, E. (2002). Education and the Environment: Strategic Initiatives for Enhancing Education in California. California Department of Education Press. Sacramento, California, s. 248.

Pieper, J. (1963). Leisure, the basis of culture. Mentor-Omega, New York.

Raffoni, M. (2006). Managing Time. US: MA: Harvard Business School Press.

Ryan, C. (1995). Islands, beaches, and life-stage marketing. In M. Conlin \& T. Baum (Eds.), Island tourism: Management principles and practice (pp. 79-94). Chichester, NY: Wiley.

Roberts, K. (1979). Contemporary Society and the Growth of Leisure. London: Longman.

Shores, K. A. (2005). The Relationship of Time Perspective to Time Allocation, Recreation Experience Preferences, and Wellness. (PhD Thesis). Texas A\&M University, US.

Sivan, A. \& Ruskin, H. (2000). Leisure Education, Community Development and Populations with Special Needs. UK: CAB Publishing.

Smith, J. W., Burr, S. W. \& Reiter, D. K. (2010). Specialization Among Off-Highway Vehicle Owners and Its Relationship to Environmental Worldviews and Motivations. Journal of Park and Recreation Administration, 28 (2), 57-73.

Stebbins, R. A. (2005). Choice and Experiential Definitions of Leisure. Leisure Sciences, 27 (1), 349-352.

Sungur, O. (2010). Korelasyon Analizi. Ş. Kalayc1 (Ed.), SPSS Uygulamalı Çok Değişkenli İstatistik Teknikleri kitabı içinde (s. 116-130). Ankara: Asil Yayın Dağıtım.

Tengilimoğlu, D., Altınöz, M., Başpınar, N.Ö. ve Erdönmez, C. (2011). Zaman Yönetimi [Time management]. H. Tutar (Ed.). Zaman Yönetimi kitabı içinde. Ankara: Seçkin Yayıncılık.

Tinsley, H. E. A. \& Tinsley, D. J. (1986). A Theory of The Attributes Benefits, And Causes of Leisure Experience. Leisure Sciences, 8 (1), 1-45.

Torkildsen, G. (2005). Leisure and Recreation Management. UK: Routledge.

Torkildsen, G. (1986). Leisure and Recreation Management. E. \& F. N. Spon, London.

Xie, J., Luo, S., Furuya, K., \& Sun, D. (2020). Urban parks as green buffers during the COVID-19 pandemic. Sustainability, 12(17), 6751.

Wang, C. C. (2008). Leisure participation, leisure motivation, and life satisfaction for elders in public senior resident homes in Taiwan. (PhD Thesis). University of the Incarnate Word, US.

Wellman, J. D. (1979). Recreational response to privacy stress: A validation study. Journal Leisure Research, 11(1), 61-73.

Wichasin, P. (2007). A Study of Thai Women As Health Tour Participant in Relation to Lifestyle and Leisure Practice. (PhD Thesis). Bournemouth University, England.

\section{BRIEF DESCRIPTION OF AUTHOR}

İhsan KURAR, Ph.D.

Independent Researcher,

E-mail: ihsankurar@hotmail.com

ORCID: https://orcid.org/0000-0001-6259-6725

Area of interest: Leisure, Recreation, Faith, Economy, Internationalisation, and Health tourism 